\title{
Novel therapeutic interventions towards improved management of septic arthritis
}

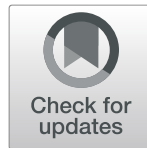

Jian Wang ${ }^{1 *}$ (D) and Liucai Wang ${ }^{2}$

\begin{abstract}
Septic arthritis (SA) represents a medical emergency that needs immediate diagnosis and urgent treatment. Despite aggressive treatment and rapid diagnosis of the causative agent, the mortality and lifelong disability, associated with septic arthritis remain high as close to $11 \%$. Moreover, with the rise in drug resistance, the rates of failure of conventional antibiotic therapy have also increased. Among the etiological agents frequently isolated from cases of septic arthritis, Staphylococcus aureus emerges as a dominating pathogen, and to worsen, the rise in methicillinresistant S. aureus (MRSA) isolates in bone and joint infections is worrisome. MRSA associated cases of septic arthritis exhibit higher mortality, longer hospital stay, and higher treatment failure with poorer clinical outcomes as compared to cases caused by the sensitive strain i.e methicillin-sensitive S. aureus (MSSA).

In addition to this, equal or even greater damage is imposed by the exacerbated immune response mounted by the patient's body in a futile attempt to eradicate the bacteria. The antibiotic therapy may not be sufficient enough to control the progression of damage to the joint involved thus, adding to higher mortality and disability rates despite the prompt and timely start of treatment. This situation implies that efforts and focus towards studying/ understanding new strategies for improved management of sepsis arthritis is prudent and worth exploring. The review article aims to give a complete insight into the new therapeutic approaches studied by workers lately in this field. To the best of our knowledge studies highlighting the novel therapeutic strategies against septic arthritis are limited in the literature, although articles on pathogenic mechanism and choice of antibiotics for therapy, current treatment algorithms followed have been discussed by workers in the past. The present study presents and discusses the new alternative approaches, their mechanism of action, proof of concept, and work done so far towards their clinical success. This will surely help to enlighten the researchers with comprehensive knowledge of the new interventions that can be used as an adjunct therapy along with conventional treatment protocol for improved success rates.
\end{abstract}

Keywords: Septic Arthritis, antimicrobial resistance, Staphylococcus aureus, Interventions

\section{Background}

Bacterial septic arthritis (SA) represents infection of the joints caused by the colonization of the joint cavity by a pathogenic bacteria. Acute bacterial arthritis represents an orthopedic emergency that needs early diagnosis and aggressive treatment to save the patient's life and risk of

\footnotetext{
* Correspondence: lijy161009@sina.com

'Department of Nursing, The Third Hospital of Jinan, Shandong Province, Jinan 250132, China

Full list of author information is available at the end of the article
}

irreparable joint degradation [1-4]. In some cases, septic arthritis may remain untreated and although the patient may survive the acute phase, but the chronic inflammatory condition may set in, which is altogether more challenging to treat [5-7].

Septic arthritis due to a pathogenic bacterial strain is mostly mono-articular involving one joint (as a typical red, swollen and painful joint). However, it may present itself as poly-articular as well ( $22 \%$ of cases) [8-10]. Old age, diabetes mellitus, cirrhosis, renal disease,

(c) The Author(s). 2021 Open Access This article is licensed under a Creative Commons Attribution 4.0 International License, which permits use, sharing, adaptation, distribution and reproduction in any medium or format, as long as you give appropriate credit to the original author(s) and the source, provide a link to the Creative Commons licence, and indicate if changes were made. The images or other third party material in this article are included in the article's Creative Commons licence, unless indicated otherwise in a credit line to the material. If material is not included in the article's Creative Commons licence and your intended use is not permitted by statutory regulation or exceeds the permitted use, you will need to obtain permission directly from the copyright holder. To view a copy of this licence, visit http://creativecommons.org/licenses/by/4.0/ The Creative Commons Public Domain Dedication waiver (http://creativecommons.org/publicdomain/zero/1.0/) applies to the data made available in this article, unless otherwise stated in a credit line to the data. 
rheumatoid arthritis, osteomyelitis, prosthetic joint, recent joint surgery, concurrent skin infection, intravenous drug use are the possible risk factors [9, 11-13]. Looking at the incidence rates, SA exhibits an annual incidence of six to ten cases per 100,000 patients per year and an associated mortality rate as high as $10-15 \%$ [4, 14-19].

The possible entry points of bacterial inoculation in the joint include, three possible routes i.e. a) direct seeding due to recent arthroplasty surgery such as prosthetic implantation or fracture fixation or joint aspiration or intra-articular steroid injection, b) through the hematogenous route from a distant infection reservoir $[20,21]$ and c) due to extension of contiguous infection underlying bone infection in cases of osteomyelitis or prosthetic infected joint with involvement of biofilm bacteria $[15,22,23]$. Such biofilm bacteria exhibit a high degree of recalcitrance towards both immune attack and antibiotics, further complicating the clinical outcome [24]. Among the etiology associated with SA, Staphylococcus aureus has been the predominant pathogen responsible for $40 \%-50 \%$ of the cases of septic arthritis and further $6 \%$ to $22 \%$ of $S$. aureus isolates being identified as MRSA, hinting towards the frequent involvement of MRSA in bone and joint infections and its rise among orthopedic settings [25-29]. MRSA septic arthritis has been reported to be associated with longer hospital says, longer courses of antibiotic therapy, comparatively more number of surgical interventions [19, 30]. In fact, MRSA infection of joints were found more likely to be inadequately treated with ineffective and inappropriate empiric therapy as compared to MSSA infections adding to higher rates of treatment failures are seen [31, 32]. Another worrisome fact remains the increasing cases of community-acquired MRSA (CA-MRSA) mediated joint infections seen in young adults or children with no history of hospital stay or contact with healthcare staff [3335]. CA-MRSA and strains display different genetic properties and different antibiotic patterns than hospital-acquired MRSA (HA-MRSA) and thus may require an altogether different set of prescribed antibiotics and treatment regimen [36, 37].

The second major challenge that calls for a search for improved management protocols is the destruction imposed by the exacerbated inflammatory process seen in patients with SA. This inflammatory response may turn chronic, causing persistent and irreversible damage to the affected joint and its architecture in a futile attempt to clear the bacterial infection $[6,9,38-40]$.

With this scenario, the need to look into new alternatives for improved management of septic arthritis new adjunct therapies that can be given along with antibiotics represents a fruitful approach. Also, current research towards approaches for down-regulation of the heightened immune response to minimize the tissue damage is also required. The present review focuses to highlight the new treatment and management strategies which need further exploration to find clinical approval and success in the fight against SA. The major focus of the present review, however remains $S$. aureus which is the predominant problem pathogen and its recalcitrance emphasizes on the need to developing new strategies for effective management and treatment of $S$. aureus mediated arthritis.

\section{Methodology}

PubMed as well as internet searches (Google search engine) were used without time restriction following use of related keywords and search terms such as MRSA, methicillin-resistant Staphylococcus aureus, S. aureus, biofilm, Septic arthritis, Phage therapy, Anti-microbial peptides applying combination of one or more key words in relevance to septic arthritis. For collecting data on proof of concept, more emphasis was laid on articles showing invitro and in -vivo efficacy studies (non-antibiotic interventions) related to bone and joint infections from 2010 onwards. Texts and authoritative Web sites were also reviewed. Articles were included if they were applicable to a) pathophysiology and disease course of septic arthritis b) management of septic arthritis c) phage therapy, AMP as antibacterial strategies and their mechanism of action d) non-antibiotic interventions used against bone and joint infections, e) anti-inflammatory management of bone and joint infections ie immunotherapies $\mathrm{f}$ ) in vitro, in -vivo and clinical cases related to studying the potential of phage therapy, AMP's, immunotherapies against septic arthritis and related to bone and joint infections (e.g osteomyelitis, prosthetic implant infections). Article pertaining to management of rheumatoid arthritis or osteoarthritis or non-bacterial causes of bone and joint damage were excluded.

Firstly, both the authors (JW, LW) screened the titles and abstracts of articles obtained from the initial search while excluding articles that did not fit into the context for this review. Further, full text of the shortlisted articles were read and relevant information abstraction performed. Information from the source documents was organized into various categories pertaining to and as per the sub-sections of the flow of the review article. Following information extraction, 189 citations were included in this review and the information was organized into the following relevant categories: Pathophysiology of Septic Arthritis, New intervention and management approaches that included AMPs, Phage therapy, Adjunct immunotherapies.

\section{Pathophysiology of septic arthritis : a closer look}

The consensus for mainstay treatment for SA still remains the complete aspiration of purulent material 
followed by long-term (at least six weeks) of antibiotics, which begins as intravenous and then by oral administration $[15,41,42]$. This treatment regimen may help to tackle the emergency period, but the infection can persist, resulting in a chronic state that may gradually lead to permanent joint damage or degenerative joint disease $[9,43]$. Therefore, before discussing the possible treatment options that are worth exploring, it is essential to understand the disease pathogenesis and what contributes to joint damage. The bacteria may gain entry into the joint space through either the hematogenous route or through direct invasion or possibly through the spread of a bone infection [41-44]. The synovial membrane has a complex architecture with dense vascularity but the vessels of the synovial intima do not have a limiting basement membrane. This allows passage of large molecules such as hyaluronic acid across the basement membrane essential to lubricate this articular cartilage $[9,13,14,45]$. But, this also enables the constant contact with blood or lymph which facilitates hematogenous entry of bacteria or phagocytes carrying bacteria to enter the synovium. Once inside the synovial space, the bacteria adhere to the synovial cells and express hostderived extracellular matrix proteins (elastin, collagen, fibrinogen, fibrin, collagen, hyaluronic acid) that aid in bacterial adherence to joint tissue [23, 46, 47]. Also, certain bacteria, such as S. aureus, Streptococcus sp,. Neisseria gonorrhoea exhibit tissue tropism for the synovium [48]. Among the bacterial factors that mediate adherence is the "Microbial surface components recognizing adhesive matrix molecules (MSCRAMMs). S. aureus expresses a myriad of an adhesive surface protein termed as MSCRAMMS that play a vital role in adherence of the cocci to the joint matrix [49-51]. This MSCRAMM group includes Clumping Factor A and B i.e ClfA, ClfB; Sdr family of proteins (SdrC, D and E); Fibronectin binding protein (FnBPA, FnBPB), collagen adhesion (CAN), Bone sialoprotein binding protein (Bbp), Elastin binding protein (Ebp), autolysins A and E etc .[9, 50, 52, 53]. It was observed that mice which was infected with a mutant strain devoid for the collagen adhesin gene, showed $43 \%$ low occurrence of septic arthritis than in the corresponding wild type [54]. Moreover, past studies have depicted that collagen-binding protein (Can) was expressed by as high as $56 \%$ of $S$. aureus isolates associated with a bone infection showing its tropism for bone and collagen matrix [55]. In another study, mice vaccinated with a recombinant form of the adhesin showed significant reduction in the sepsis-associated mortality rate ( $13 \%$ vs $87 \%$ in non-vaccinated group) [56]. Similarly, guniea pigs infected with mutant $S$. aureus strain i.e defective in expression of fibronectin-binding protein showed three times less adherence to miniplates implanted in than normal wild type strains [57] stressing on the critical role that fibronectin-binding proteins (FbpA and $\mathrm{FbpB}$ ) play in pathological course of SA. Once adhered, the bacteria multiply using the synovial milieu as an ideal culture medium. Recent evidence have suggested the existence of biofilm-like clumps or agglomerates for S. aureus and MRSA strains in the synovial fluid of patient suffering from chronic joint infections and septic arthritis [57-59]. Pestrak et al. [60] highlighted on the role of host factors such as fibrinogen and fibronectin in the formation of such biofilm-like aggregates within the joint fluid. These biofilm bacteria exhibit altered phenotypes called small colony variants (SCVs) that exhibit slow growth and such forms are capable of intracellular persistence within the osteoblasts, fibroblasts, neutrophils etc. This property enables the pathogen to evade the immune attack while displaying higher recalcitrance towards deployed antibiotics [6164]. Such biofilm clumps in the synovial fluid and nearby tissue act as communicating niches of hiding bacteria that may later re-populate to new sites leading to a second wave of re-infection and re-seeding $[65,66]$. Besides this, $S$. aureus secretes virulence factors such as enterotoxins, protein A, capsular polysaccharide (aid in evasion from phagocytosis and promote intracellular survival of capsular strains) along with staphylococcal toxic shock syndrome toxin (TSST-1) that acts as superantigen for non-specific activation of a large number of T-cells play important role in progression of the disease [67, 68]. It has been studied that $\alpha$-hemolysin also causes blood coagulation, platelet aggregation, neutrophil adherence and lymphocyte DNA degradation [69]. CA-MRSA expresses Panton-Valentine toxin (unlike HA-MRSA) which enables the cocci to survive within the neutrophils and even multiply, thus contributing to the development of fulminant joint infection even in young healthy children and adults [70, 71]. It is associated with MRSA cases that cause more invasive osteoarticular disease requiring higher surgical interventions, longer stay in hospital and increased rates of septic shock and prolonged antibiotic treatment [72].

Following a bacterial seeding, the bacterial products and toxins initiate the inflammatory cascade characterized by an influx of immune cells, neutrophils , activation of macrophages, and release of inflammatory cytokines such as IL-1 $\beta$, IL-6, TNF- $\alpha$, MIP-2, Granulocyte-macrophage colony-stimulating factor (GM-CSF) [9, 43]. Toll-like receptors (TLR's) play a key role as transmembrane proteins involved in recognizing bacterial pathogen-associated molecular pattern molecules (PAMP's) and up-regulated expression of TLR's results in nuclear translocation and activation of transcription factor NF-kB that further promotes secretion of pro-inflammatory cytokines and neutrophil infiltration [73-75]. These cytokines recruit more 
phagocytic cells to the site and also activate host Creactive protein (CRP) levels of the liver which in turn activate the complementary pathways. The phagocytosis of bacteria by macrophages, synoviocytes, PMNL's release more lysosomal enzymes and reactive oxygen species (ROS) and further induction of cytokines, leading to the development of redness, swelling, pain [23, 39, 76]. This inflammatory reaction mounted by the host is protective and along with antibiotic therapy may help to contain the spread of infection further. But, if in case the infection is not cleared, there continues an ongoing battle of the host mounted an immune response against bacteria and the immune system exacerbates rather than ameliorates the outcome of septic arthritis $[2,13,21$, 77]. Soon, the T-cells also start to enter the joint cavity and get activated upon antigen presentation supported by host antigen-presenting cells (APC's). The heavy influx of T-cells, B-cells, macrophages causes thickening of the synovial membrane. High levels of cytokines induce the release of host matrix metalloproteinases (stromelysin and collagenases) and lysosomal enzymes, which further worsen joint degradation [78, 79]. As the intraarticular pressure rises, the synovial vasculature may get compressed with thrombosis and further permanent damage to the articular cartilage impeding the blood and oxygen supply as well. This may extend to the articulating bone resulting in serious damage to bone growth, especially in children, and causing permanent cartilage erosion [13, 43, 80]. A schematic illustration of the pathophysiology and damage involved is presented in Fig.1.

\section{New intervention and management approaches}

The new approaches against SA have been divided broadly as anti-bacterial strategies' and immune based management options that are worth exploring. Each approach has been discussed in terms of its mode of action and supported with recent data (in vitro and in vivo studies) and discussion of the major findings.

\section{Anti-microbial peptides (AMP's)}

Antimicrobial peptides also referred as host defense peptides (HDP's) present a promising class of anti-bacterial agents that exhibit potent antimicrobial activity against broad range of pathogenic microorganisms. AMPs are highly conserved, short (15-50) amino acid sequences

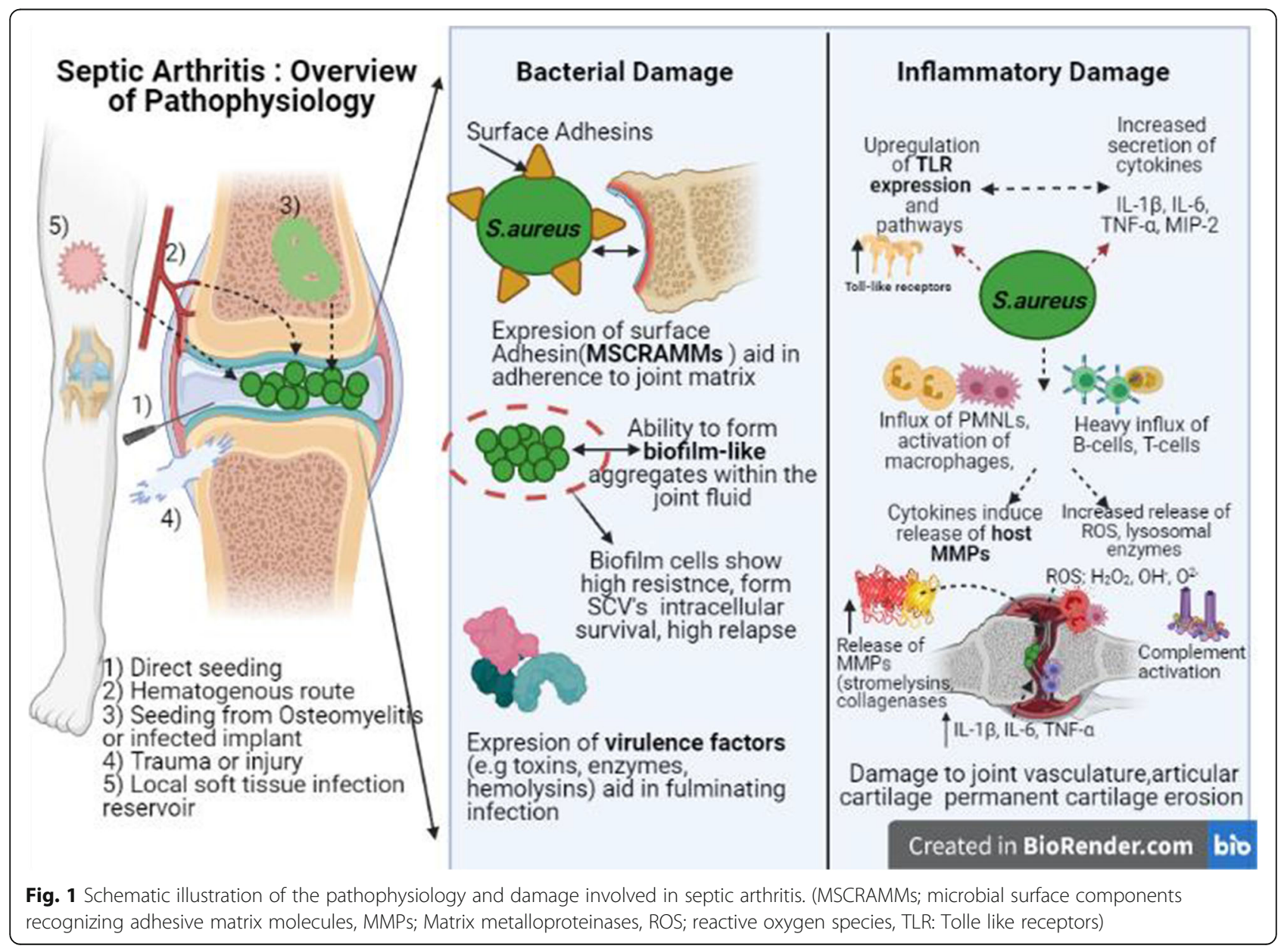


that are effector molecules of the innate immunity and can be of plant, animal or microbial origin [81, 82]. AMP's are mostly cationic peptides that show rapid killing and are effective against range of drug-resistant pathogens [83, 84].

\section{Mechanisms}

The classical mode of action of these peptides includes direct killing via both membrane targeting as well as non-membrane targeting routes (Fig.2). The membrane targeting includes binding of the AMP through its binding domain to the bacterial membranes. The outer surface of both Gram-positive and Gram-negative bacteria contain structures [Lipopolysaccharide (LPS), phospholipids, teichoic acids etc.] that impart a net negative charge allowing easy electrostatic interaction with cationic AMP's. Once bound, the next step includes the formation of membrane-embedded pore within the lipid bilayer (as explained through torroidal, barrel stave or carpet model) [85-87]. Few AMP's have also been shown to cause damage by targeting internal targets within the bacterial cell such as disruption of vital proteins, enzymes, DNA/RNA, protein folding etc. [8890] without causing substantial membrane permeabilization but still leading to cell death.

Besides, the membrane damage and direct killing, the other mechanisms recently highlighted include the immune-modulatory ability of AMP. The immunomodulatory functions displayed by AMPs include: chemotaxis of immune cells thus aiding faster clearance and more effective resolution of resident bacteria, activation of immune cells but in a regulated and controlled manner, interference with Toll-like receptor (TLR) pathways that mediate the release of pro-inflammatory cytokines and reactive oxygen species, induction of antiinflammatory cytokines essential to optimize the heightened inflammatory process, scavenging of bacterial endotoxins and their inactivation as well as promoting wound healing and angiogenesis etc. [91-93]. The major class of AMP i.e cathelicidins and defensins act as potent chemoattractants via their ability to bind chemokine receptors, leading to activation and recruitment of several immune cell types, including monocytes, neutrophils, dendritic cells and also the T-cells [94-96]. This

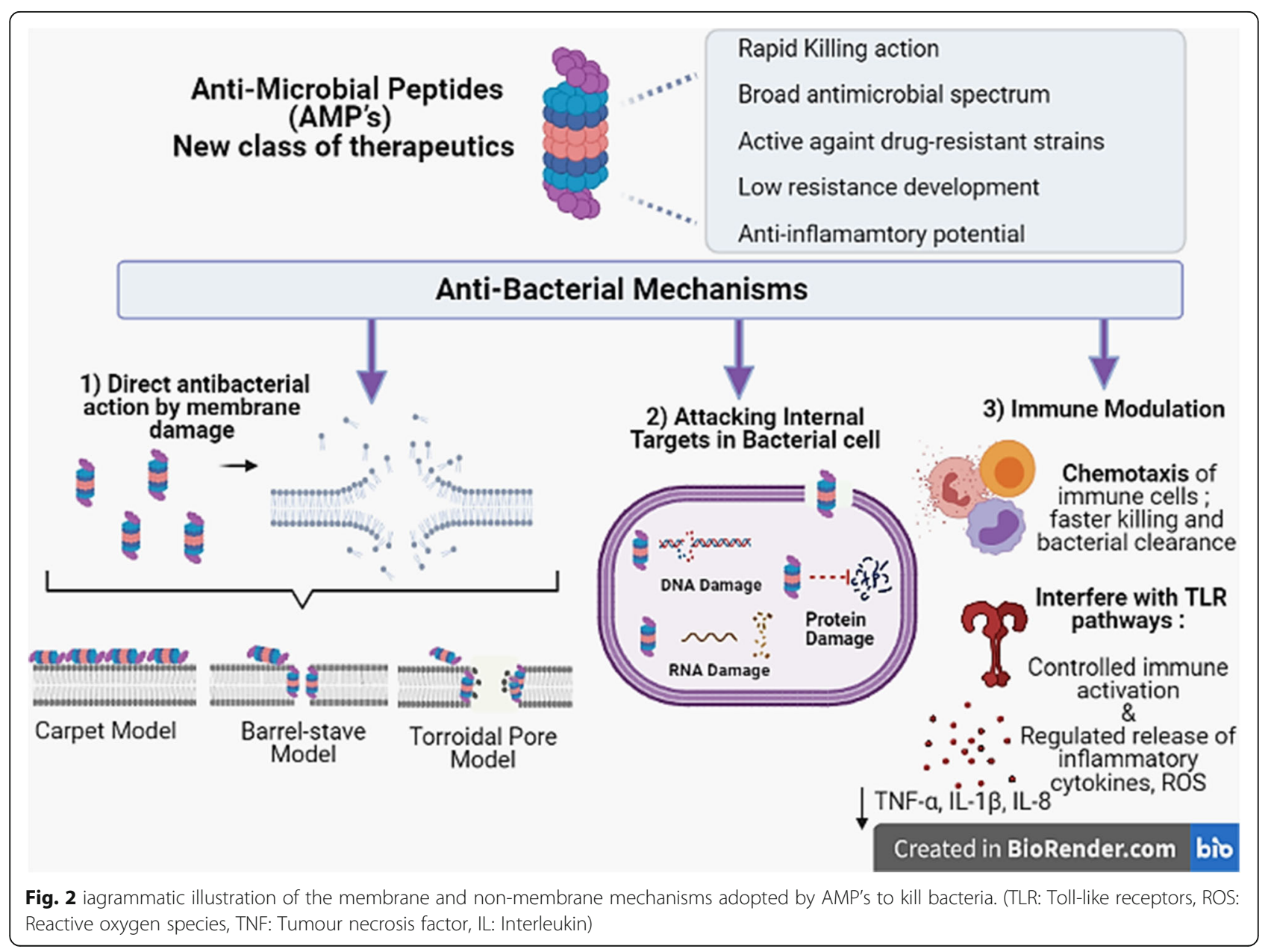


recruitment may actually enhance the bacterial clearance. Also, the immune cells recruited by AMPs may also, play a regulatory function in balancing the inflammatory process. Secondly, AMPs modulate the activation of macrophages and dendritic cells by interacting with specific Toll-like receptor (TLR) ligands and by perturbing their pathways thus preventing undue activation of macrophages and dendritic cells [97-99]. For example, LL-37 suppresses the TLR-2 and TLR-4 induced production of TNF- $\alpha$, IL-1 $\beta$, IL-8 $[97,100]$. Similarly, the 13mer Indolicidin, inhibited Escherichia coli O111:B4 LPS induced TNF- $\alpha$ secretion even when added at a delay of one hour [101]. To add to this, innate defense regulators (IDR) which are bactenecin-derived host defense peptides such as IDR-1002 have also shown to downregulate the heightened immune response by decreasing production of TNF- $\alpha$, IL-6, IL-8, and nitric oxide which is triggered by TLR ligands [102, 103]. Another synthetic peptide i.e IDR-1018 and clavanin A increased the levels of anti-inflammatory cytokine IL-10. In addition, AMP's are able to scavenge the endotoxin LPS thus preventing the binding to TLR4 and further inflammatory activation [104]. LPS-scavenging and anti-endotoxin activity was reported while studying frog dermaseptin-derived peptides [105] and thrombin-derived C-terminal peptides (TCPs)].

AMP's can thus work both as anti-bacterial killing peptides as well as participating in normalization of the deranged immune that causes significant tissue damage (even after acute episode has subsided) and thus represent an ideal option in the fight against management and treatment of SA. Moreover, AMP's have been shown to work in a synergistic fashion when used together with conventional antibiotics $[106,107]$ making them ideal to be used as an adjunct therapy.

\section{AMP's and Septic Arthritis}

Although the research targeting use of AMP's against bacterial arthritis is scarce, we present few important findings. Varoga et al .[108] reported enhanced expression of human $\beta$-defensin-2 (HBD-2) in synovial membranes that were exposed to bacteria (using a stable synoviocyte line K4IM) mimicking a case of septic arthritis. The study showed that bacteria-colonized synovial membranes displayed comparatively higher levels of human $\beta$-defensin-2(HBD-2) peptide than unexposed samples. This suggests the involvement of these cationic peptides in intra-articular defense mechanisms and their role in regulating the pathological course of septic arthritis.

Studies also highlighted the protective role of AMP's (HBD1, HBD2) as part of innate system of the articular cartilage against infection and emphasized that purified or recombinant AMP's represent potential therapeutic agents that can be administered in septic arthritis to further boost the innate resistance system of the synovial tissue [108-110].

Recently, Elizagic et al. [111] investigated the antimicrobial activity of peptides derived from C-type Lectin Domain Family 3 Member A (CLEC3A) against septic arthritis. CLEC3A is a cartilage-specific protein that is present in articular cartilage and also in growth-plate cartilage tissue in both resting and proliferating types. Researchers designed peptides and recombinantly expressed CLEC3A domains and in vitro assays using these recombinant peptides exhibited significant killing activity against $E$. coli, $P$. aeruginosa and $S$. aureus by membrane pore formation and permeabilization and also showed reduced bacterial adhesion when titanium implants were coated with recombinant CLEC3A peptides. This hints towards their potential therapeutic use against prosthetic-induced cases of septic arthritis. Another advantage offered is that since CLEC3A-derived peptides are normally expressed in the articular cartilage system under physiological conditions, using them would lead to no or minimal immunogenic reaction thus prolonging their retention in vivo.

Another study by Ries and co-workers [112] studied anti-bacterial efficacy of LyeTxI-b, a synthetic peptide derived from Lycosa erythrognatha spider venom in mice model of $S$. aureus-induced arthritis. Results indicated that Lye Txl-b was able to significantly reduce the bacterial load in the affected joint space and the simultaneous reduction in the number of inflammatory cell recruitment in the bacteria challenged joint. Also, when co-therapy of Lye TxI-b was given with clindamycin, a higher reduction in the levels of IL-1 $\beta$ cytokine (a major cause of tissue destruction) and CXCL1 chemokine in the joint were observed when compared to non-treated joints. This indicates towards potential role of this peptide as a promising adjunct strategy for better control of infection and inflammation in SA. Table 1 delineates the recent new developments pertaining to improved delivery and efficacy of various AMP's showing potency against the pathogens commonly associated with bone and joint infections.

\section{Phage therapy: a new era of treatment}

The use of lytic bacteriophages to kill pathogenic bacteria is referred to as phage therapy. Bacteriophages perfectly fit into the class of safe and potent antimicrobial agents and the reasons are many-fold. Firstly, from a clinical standpoint, phage therapy represents a safe approach and exhibits little or no history of adverse effects or tissue toxicity [120,121]. Secondly, phages owing to their self-replicating nature exhibit the unique property of auto-dosing at the expense of host-pathogen [122, 123]. Thirdly, phages being selective in their action, do 
Table 1 New Developments related to AMP research against Bone and Joint Infections

\begin{tabular}{|c|c|c|}
\hline$\overline{A M P}$ & Study Highlights & References \\
\hline $\begin{array}{l}\text { Engineered chimeric bifunctional peptides } \\
\text { (TiBP1-GGG-AMP, and TiBP2-GGG-AMP) }\end{array}$ & $\begin{array}{l}\text { - Two bi-functional chimeric peptides synthesized with an aim to strongly bind to ti- } \\
\text { tanium substrate (high affinity) while retaining antimicrobial motif free. } \\
\text { - Significant reduction in bacterial adhesion and colonization of S. aureus, S. mutans } \\
\text { and E. coli as tested. }\end{array}$ & [113] \\
\hline $\begin{array}{l}\text { OP-145 incorporated into Polymer-Lipid Encap- } \\
\text { sulation Matrix (PLEX)-coating }\end{array}$ & $\begin{array}{l}\text { - Breij and co-workers incorporated a synthetic peptide OP- } 145 \text { into PLEX coating to } \\
\text { obtain high peptide levels for prolonged periods at the implant-tissue interphase. } \\
\text { - PLEX coated nails inserted into rabbits inoculated with S. aureus. } \\
\text { - Result showed sustained release of OP- } 145 \text { from plex coatings into the joint space } \\
\text { and around the nails. } \\
\text { - Effective resolution of induced infection in } 67 \% \text { of test animals within } 28 \text { days as } \\
\text { shown by culture tests. }\end{array}$ & [114] \\
\hline $\begin{array}{l}\text { Five Artificial Peptides synthesized from } \\
\text { optimized peptide library }\end{array}$ & $\begin{array}{l}\text { - Bormann and co-researchers synthesized short artificial AMPs using solid phase pep- } \\
\text { tide library. } \\
\text { - Later, studied their anti- biofilm potency and their effect on human osteoblast cells. } \\
\text { - Peptides showed marked reduction in biofilm formation by S. aureus, E.coli, P. } \\
\text { aeruginosa, MRSA and MSSA strains as tested by microcalorimetry and FISH. } \\
\text { - Peptides able to significantly reduce internalization of bacteria within osteoblast cells } \\
\text { with no effect of viability of human osteoblast cells. }\end{array}$ & [115] \\
\hline $\begin{array}{l}\text { Novel in house designed potent ultrashort } \\
\text { AMP i.e RBRBR }\end{array}$ & $\begin{array}{l}\text { - Research team developed novel in house designed potent ultrashort AMP i.e RBRBR } \\
\text { and encapsulated it in chitosan based nanoparticles using ionotrophic gelation } \\
\text { method (RBRBR-CS-NP). } \\
\text { - Encapsulated peptide showed progressive sustained release till } 14 \text { days. } \\
\text { - Signficant decrease in S. aureus counts by three log counts with } 98 \% \text { inhibition of } \\
\text { biofilm formation. } \\
\text { - No toxicity against mammalian cells and human erythrocytes. }\end{array}$ & [116] \\
\hline LL-37 & $\begin{array}{l}\text { - Kang and co-researchers developed } 24 \text { hour S. aureus biofilm on cobalt chromium } \\
\text { discs followed by treatment with LL-37, AgNP's and conventional antibiotics } \\
\text { combinations. } \\
\text { - LL-37 effective in decreasing counts of S. aureus by as high as four log reduction in } \\
\text { CFU and this was even more than combination groups i.e AgNP's and rifampin and } \\
\text { even combination of gentamycin and rifampin. } \\
\text { - Potential application of LL-37 against bone and joint related biofilm mediated infec- } \\
\text { tions strongly advocated. }\end{array}$ & [117] \\
\hline HHC36 peptides & $\begin{array}{l}\text { - Chen and co-workers developed a Pandora box approach i.e a novel system promot- } \\
\text { ing on demand release of AMP in and around the affected joint area and implant } \\
\text { when bacterial infection occurs and lowers the surrounding pH. } \\
\text { - This Pandora box was loaded with HHC36 peptide inside the specially designed } \\
\text { titania nanotubes (Ti-NTs) nanotubes and "closed" (surface-modified) with a pH- } \\
\text { responsive molecular gate. } \\
\text { - The poly (methacrylic acid) (PMAA) swelled under normal conditions (pH 7.4) and } \\
\text { collapsed under bacterial infection when pH drops below } 6.0 \text { allowing release of } \\
\text { AMPs to kill bacteria immediately. } \\
\text { - This approach exhibited excellent activity against MRSA, E. coli, P. aeruginosa thus } \\
\text { representing a novel smart drug delivery technology worth exploring. }\end{array}$ & [118] \\
\hline $\begin{array}{l}\text { Romo1-Derived Antimicrobial Peptide (AMPR- } \\
\text { 11) }\end{array}$ & $\begin{array}{l}\text { - Lee and team developed AMPR-11, the antimicrobial peptide (AMP) derived from } \\
\text { mitochondrial nonselective channel Romo1. } \\
\text { - Peptide represents a novel class of fast acting AMP exhibiting broad spectrum } \\
\text { antibacterial activity against range of clinical pathogens and multi-drug resistance } \\
\text { (MDR) strains. } \\
\text { - Exhibits unique mechanism of killing which includes bacterial membranes by } \\
\text { interacting with cardiolipin and lipid A. } \\
\text { - Exhibited significant activity against intracellular invading bacteria and superior } \\
\text { in vivo efficacy in murine model of sepsis. }\end{array}$ & [119] \\
\hline
\end{tabular}

not alter or disrupt the normal flora, unlike long-term antibiotic-based therapy which poses significant damage to the body's normal flora. Phages also exhibit synergy when given along with antibiotics as co-therapy, further decreasing the frequency of emergence of resistant mutants [124-126]. Phage-based therapeutics have resurfaced again as they exhibit potent efficacy against a range of bacterial infections especially those caused by drug-resistant strains and this approach warrants further work [127-129].

\section{Mechanisms}

Lytic phages work as killing machines. They start their process of infection after adsorption to their particular 
host bacterium through specific receptors. Soon after attachment, they inject their genome into the host cytoplasm and utilize the host's proteins and machinery to reproducing within and assemble into a large number of progeny phages. Finally, the new progeny phages lyse their host bacteria and get released to start another round of infection. Besides this conventional mode of killing, phages also exhibit anti-biofilm activity [130, 131]. This is particularly important as recent studies have highlighted on the presence of free-floating bacteria in clumps or as biofilm-like aggregates seen in the synovial fluid of infected joints and being involved with the pathogenesis of infectious arthritis [24, 57, 132] Dastghyeb et al .[58] demonstrated that methicillin resistant $S$. aureus (MRSA) was able to form biofilm-like aggregates seen in human synovial fluid (SF) present within the joint cavity. These biofilm-like agglomerations tend to decrease the ability of the neutrophil-mediated killing of the cocci within the synovial fluid [57] while making the pathogen more recalcitrant. Phages are equipped with virion-associated de-polymerases and peptidoglycan degrading endolysins that degrade the biofilm matrix, penetrating the deeper layers of biofilm and attacking bacterial cell walls $[132,133]$. Phages are also able to bind and lyse the bacteria that are metabolically dormant or the slow-growing persister cells (low-metabolic cells) that may reside within the deeper layers of host tissue [134]. These slow-growing cells exhibit altered phenotypes and often escape from the attack of antibiotics and thus re-emerge to start another round of infection days or months after the primary antibiotic therapy has stopped. S. aureus and S. epidermidis are known to form small colony variants (SCVs) that have been found associated with fibroblasts in joint infections and these SCV's are responsible for intracellular persistence, re-infection, and treatment failures $[63,64,135]$. Evidence studies report that $S$. aureus is also able to survive intracellular and successful internalization within the bone cells, fibroblasts, osteoblasts, macrophages, epithelial cells [136-140] and by this, it may evade its clearance from the immune cells as well as from the administered drugs. However, studies have indicated towards the ability of phages to penetrate the eukaryotic cells and attack the intracellular populations of pathogens that may hide within, thus reducing recurrent infections $[126,141]$.

Another major aspect of phages is their potential role (other than lytic) in modulating the immune system at different levels. Studies report that phage therapy can help to correct the heightened levels of inflammation seen in many infections in different ways [142-146]. These may include; 1$)$ the ability of phages to reduce high levels of pro-inflammatory cytokines (TNF- $\alpha$, IL-1, IL-8, MIP-1), 2) through LPS binding 3) inhibition of excessive reactive oxygen species (ROS) species production and 4) induction of synthesis of potent antiinflammatory cytokine essential in limiting cell and tissue injury during bacterial infections IL-10. Phage ISP specific for $S$. aureus phage showed induction of antiinflammatory IL-1 receptor antagonist (IL-1RA) synthesis by human monocytes thus leading to the repression of pro-inflammatory cytokines [147]. Phages have also been shown to down-regulate the expression of TLR4 and TLR2 expression which are key sensors involved in the detection of $S$. aureus pathogen via interacting with specific PAMPs that leads to activation of NF- $\mathrm{kB}$, leading to cytokine production, cell infiltration, phagocytosis etc .[148, 149]. Zhang and co-workers [150], S. aureus phage vB_SauM_JS25 inhibited the production of proinflammatory cytokines possibly via inhibiting the NF- $\kappa B$ (a key transcription factor for encoding proinflammatory cytokines) phosphorylation which led to the decline in the levels of inflammatory cascade mediators. Thus, it is evident that besides its killing ability, phages also lead to down-regulation of excessive immune responses, thus contributing to the maintenance of immune homeostasis. A detailed representation of the different mechanisms through which phage may help to resolve septic arthritis infection have been depicted in Fig.3.

\section{Phage therapy and SA}

Phages have been tested against bone and joint infections including osteomyelitis and prosthetic or orthopedic implant infections but studies strictly focused on the use of phages in resolving cases of acute septic arthritis is still scarce. However, conditions such as osteomyelitis or bacterial colonization of orthopedic implants closely mimic and act as important predisposing conditions that may lead to septic arthritis involving the joint space. Table 2 depicts the outline of recent in-vitro, invivo and clinical cases wherein phages showed excellent efficacy in treating various bacterial infections of bone and joints (including those caused by MRSA and other drug-resistant strains).

Septic arthritis represents an orthopedic emergency which is tackled by surgical interventions along with high doses of intravenous antibiotics given immediately within the first 24 hours $[7,155,156]$. Phages can also be administrated intravenously during this emergency period in order to provide more effective control of the infection process and associated sepsis as demonstrated in past studies [122, 157-160]. In a recent study by Ferry and co-workers [161], a cocktail of $S$. aureus specific bacteriophages $\left(10_{10} \mathrm{PFU} / \mathrm{ml}\right)$ impregnated in hydrogel were given to a 49-year old patient suffering from megaprosthetic infection as part of salvage therapy along with debridement, antibiotics and implant retention (DAIR). The selected phages showed sustained release from the 


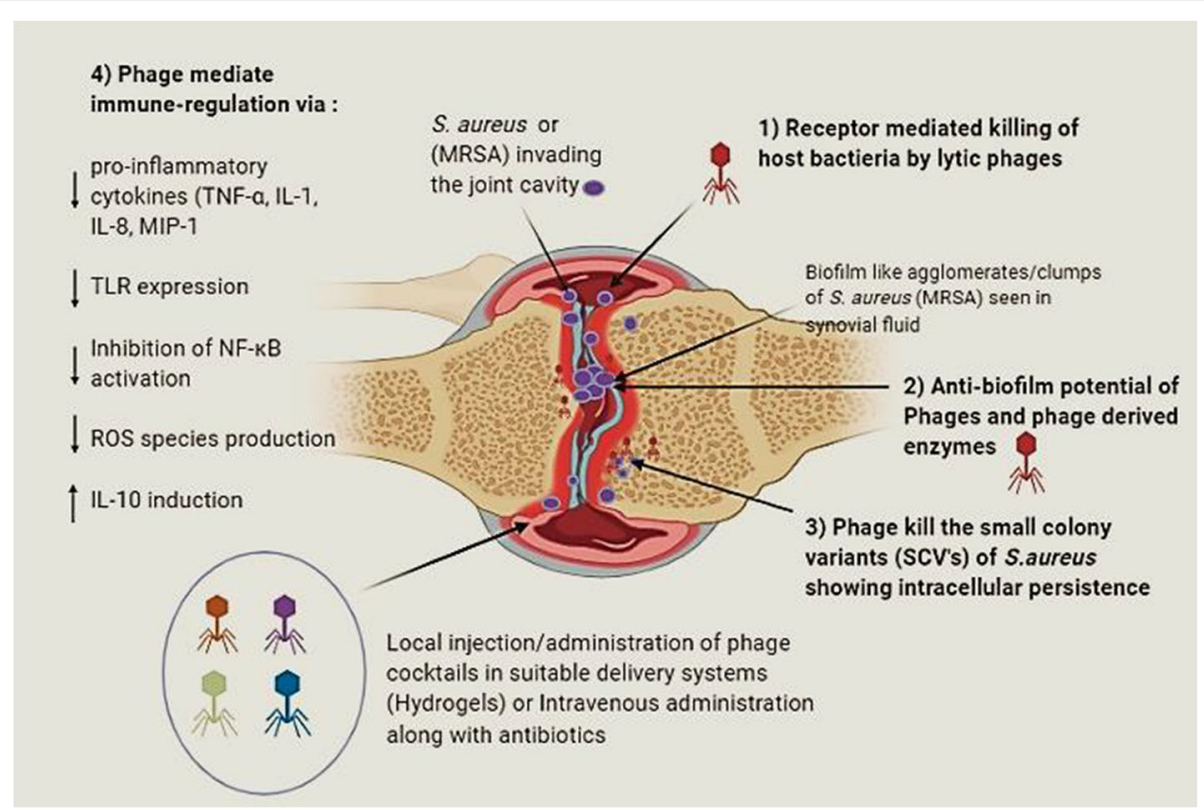

Fig. 3 Detailed representation of the different mechanisms through which phage may help to resolve septic arthritis infection. Image created using Biorender (SCV's: small colony variants, TNF: tumor necrosis factor, TLR: toll-like receptors, NF-KB : IL-Interleukin, ROS: reactive oxygen species; MIP: macrophage Inflammatory Proteins)

Table 2 Recent studies demonstrating the therapeutic success of phage therapy in treatment of bone and joint infections

\section{Outline of Study}

Therapeutic efficacy of cocktail of five phages against S. aureus given intraperitoneally at a dose of $10^{8} \mathrm{PFU} / \mathrm{ml}$ in a rat model of joint infection (alone as well as along with vancomycin)

\section{Major Findings}

- Phage treatment alone led to 5 -fold reduction in bacterial load in the peri-implant tissue.

-When given in combination with vancomycin, 6.2 fold reduction occurred.

- 22.5 fold decrease in bacterial burden in the joint tissue unlike sham treated animals.

- Phage treated animals showed marked reduction in swelling and joint inflammation.

- Dual Hydrogel based system exhibited release of both agents i.e phage and linezolid in a slow sustained manner in the joint tissue

- Combination therapy showed synergistic effects.

- Highest decrease in bacterial burden, improvement in joint mobility and lowered cytokine levels seen in combination group.

- Test rabbits recovered from the infection within two weeks with marked decline in local oedema, erythema and induration.

- Phage treated group showed new bone formation and improved histopathology.

- Phage therapy initiated 3-6 weeks post development of experimental osteomyelitis.

- Test animals received four repeated doses of seven MRSA phages in a cocktail mix given at the interval of $48 \mathrm{~h}$.

- Clinical case study of salvage phage therapy in a 72 year old male with a chronic MRSA prosthetic joint infection.

- Infection persisted even after two DAIR procedures.

- Patient administered three doses of $2.7 \times 10^{9}$ PFU through i.v route along with daptomycin.

\section{Clinical case:}

- 42-year old man with multidrug-resistant left tibial infection was positive for multidrug resistant strains of Klebsiella pneumoniae and Acinetobacter baumannii.

- Patient received combination therapy of bacteriophage (intravenous bacteriophage therapy at $10^{7} \mathrm{PFU} / \mathrm{mL}$ titers) and antibiotics.

Reference

[151]

作

Phage MR-5 alone as well as mixed with linezolid was encapsu-

followed by MRSA inoculation.

- To evaluate efficacy of S. aureus specific bacteriophage cocktail formulations against MRSA employing rabbit model of$$
\text { histopathology. }
$$
- Phages were able to sterilize the patient's severe chronic MRSA
joint infection with a single virulent bacteriophage given i.v for
three days giving negative cultures.

- Within days of phage administration, the patient showed improved wound healing, decrease in the chronic bone pain.

- Negative bacterial cultures obtained for both the causative bacteria and patients' leg was thus saved from amputation surgery. 
hydrogel with stable titers for at least $6 \mathrm{~h}$ showing a significant reduction in numbers in vitro. This approach clearly demonstrates the feasibility of the use of bacteriophage cocktails along with surgical interventions that can be administered either intravenously along with antibiotics or can even be placed locally entrapped within such hydrogel systems during the debridement procedure adopted. A similar approach was used with PhageBioderm, a polymeric bandage that was directly placed at wound site allowing the release of phages slowly over an extended period aiding in healing of infected venous ulcers and poorly healing wounds [162, 163]. Another possibility can also be a direct injection of phage preparations into the affected joint lesion area for improving phage targeting inside the body and also reducing the issues related to systemic phage clearance from the blood [152]. Phages have been successful in saving patient's life from overwhelming sepsis as reported by recent studies. Dupplesis et al. [164] reported the successful administration of phage cocktail against refractory $P$. aeruginosa bacteremia in a 2-year-old boy that showed allergy to antibiotics. Phage cocktail was given intravenously every $6 \mathrm{~h}$ for a period of $36 \mathrm{~h}$. Blood cultures turned and thus phage cocktails were able to bring complete sterilization of the blood. In another case of acute $P$. aeruginosa septicemia, $50 \mathrm{ml}$ of lytic phage cocktails were administered in a $6 \mathrm{~h}$ i.v infusion for 10 days. Post-phage therapy, the blood cultures turned negative, and a drop in CRP with disappearance in fever were seen within days [165]. These findings indicate the possible role of phage administration in cases of septic arthritis both during and after the emergency period to prevent joint damage, acute sepsis, and mortality and development of chronic SA.

\section{Adjunctive immunotherapies}

In SA, killing the bacteria may not be the sole option for successful disease management and strategies aimed to abrogate the progressive bone destruction by balancing the heightened immune response is equally important. Although the interplay between host cytokines, interleukins, host immune cells , bacterial clearance and progression of infection is a highly complex network and is beyond the scope of the present review, but few important therapeutic targets with possibility to use as adjunct

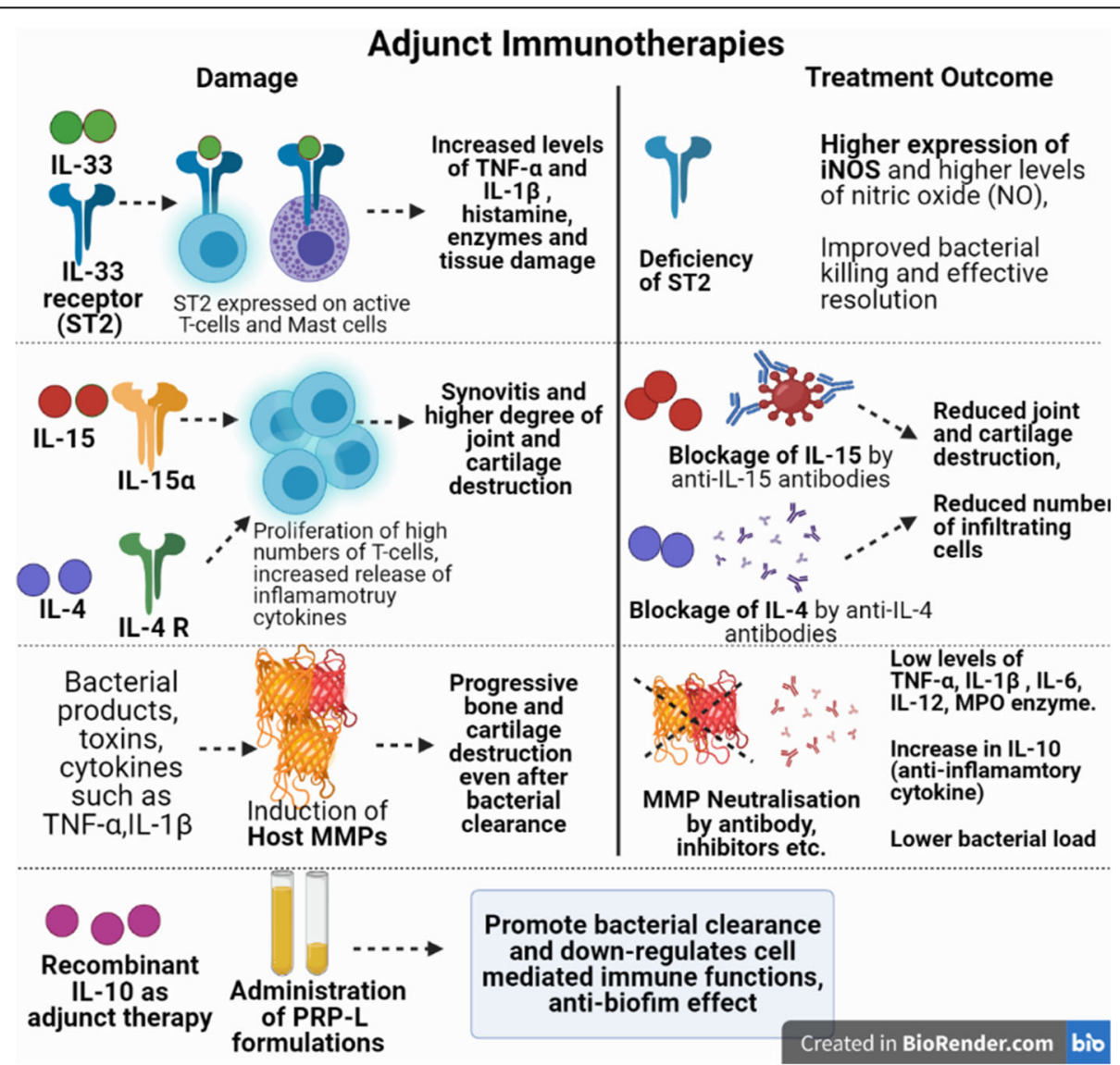

Fig. 4 Schematic illustration of the various adjunct immunotherapy based treatments against septic arthritis (iNOS: Inducible nitric oxide synthase, PRP-L: platelet rich plasma lysate, MMPs: Matrix metalloproteinases) 
therapy have been discussed as follows and is also depicted in Fig.4.

\section{Matrix metalloproteinases (MMPs) based therapy}

MMP's represent important mediators in the synovial tissue destruction and pathogenesis of septic arthritis. These are calcium- and zinc dependent endopeptidases and have been classified as 24 different members (collagenases, gelatinases, stromelysins, matrilysins, membrane types etc.) [166, 167].MMP expression is elevated in septic and aseptic arthritis and this contributes to tissue destruction owing to their capability of degrading extracellular matrix (ECM) [168-171]. Bacterial products and their toxins, cytokines such as TNF- $\alpha, I L-1 \beta$ and also the transcription factor, NF-kB have been implicated inactivation of these endopeptidases. As a result, inflammatory cells, synovial fibroblasts, chondrocytes, resident articular cells, synovial fibroblasts, osteoclasts start the release of MMP's thus adding to their heightened level s[167, 172-174]. These elevated levels of MMP's cause progressive bone and cartilage destruction in septic arthritis even after bacterial clearanc e[166, 175]. Therefore, one approach directed towards neutralization of key MMP's and studying the effect on disease progression seems worth exploring. Gjertsson et al .[175] had highlighted the role of MMP-7 in the joint destruction in a $S$. aureus induced mouse model of arthritis. The team studied the course of infection in MMP-7 deficient mice and wild type controls which were experimentally inoculated via intravenous route with S. aureus LS-1 followed by development of septic arthritis. Findings showed that MMP-7 deficient mice showed reduced and less severe destruction due to arthritis both clinically and histologically although no effect on the impact on clearance of bacterial load was seen.

Recently, Sultana et al. [167] studied the protective effect of MMP-2 neutralisation on the course of S. aureus septic arthritis in mice and effect on cytokine regulation. MMP-2 is involved in activation of pro-IL-1 $\beta$ to activeIL-1 $\beta$ as well as in activation of other inflammatory cytokines i.e TNF- $\alpha$ andIL-1b [176]. Sultana and coworkers administered MMP-2 inhibitor ( $\mathrm{N}-[(1,10-$ Biphenyl)-4-ylsulfonyl]-D-phenylalanine) at a dose of 5 $\mathrm{mg} / \mathrm{kg}$ given intraperitoneally $24 \mathrm{~h}$ post- infection with S. aureus and continued up to 15 days. Results depicted that as compared to untreated animal group, the animals treated with MMP-2 inhibitor showed a) higher reduction in associated swelling of the joints b) significantly reduced bacterial counts seen in synovial tissue at day 3 and day 9 post-infection c) significant decrease in levels of TNF- $\alpha$, IL-1 $\beta$, IL-6, IL-12 and d increase in IL-10, decrease in myeloperoxidase (MPO) enzyme levels. These findings clearly indicate that neutralisation of MMP-2 represents a potential target to prevent joint destruction and regulate the cytokine levels during the arthritic episode. Further, Sultana and co-researchers [174] also evaluated the effect of combined therapy of MMP-2 and tumor necrosis factor receptor 1 antibody (TNFR1) on episodes of $S$. aureus induced septic arthritis in mice. Combined treatment group showed marked reduction in bacterial counts and low levels of proinflammatory cytokines in serum and synovial tissues as well as low arthritis index. Also, expression of cyclooxygenase (COX-2) and iNOS was significantly reduced in the combination group thus suggesting that such combination therapy represents a promising option in reducing the bacterial burden in the infected joint tissue as well as in decreasing the cartilage destruction and associated inflammatory damage in septic arthritis.

\section{IL-33 receptor (ST2) Deficiency/Blockage as possible Target}

Interleukin-33 (IL-33) is a member of the IL-1 cytokine family and it binds to its receptor ST2 expressed on activated mast cells and Th2 cells. The IL-33/ST2 axis plays key roles in joint inflammation and immune mediated diseases. Staurengo-Ferrari et al .[177] investigated the role of IL-33 receptor (ST2) deficiency on the outcome of septic arthritis. Results depicted that ST2-/- mice showed higher reduction of hyperalgesia and lower paw oedema scores. Also, wild type mice showed increased levels of TNF- $\alpha$ and IL-1 $\beta$, higher cell infiltration as compared to the ST2-/- mice. The bacterial clearance was also higher from joint and spleen as seen in ST2-/mice and the infection remained localized and this was possibly due to the fact that higher expression of iNOS and higher levels of nitric oxide (NO) was observed in ST2-/- mice. Thus, it was concluded that ST2 deficiency was associated with induction and enhancement of Th1 cell types leading to activation of neutrophils and macrophages with IFN- $\gamma$ production, enhanced iNOS expression and improved bacterial killing resulting in effective resolution of infection thus suggesting that ST2 deficiency is beneficial in S. aureus-induced septic arthritis.

\section{IL-15 blockage as possible target}

Hennigson et al. [178] investigated the role of IL-15 in S. aureus mediated arthritis. They used both IL$15 \mathrm{knockout}$ as well as wild-type control mice treated with anti-IL15 antibodies. Systemic arthritis was induced in mice by injecting (i.v) toxic shock syndrome toxin (TSST)-1 secreting strain i.e $S$. aureus LS-1.Results showed that after inoculation, comparatively less severe arthritis was observed in mice with deleted IL-15 gene and in the mice group treated with antibody to IL-15 unlike wild-type mice. The severity of synovitis and degree of joint and cartilage destruction was significantly less with reduced number of osteoclasts seen in gene knockout mice as well as mice treated with anti-IL-15 
antibody as compared with normal wild type controls. This indicates that IL-15 is a mediator of joint destruction and serves as a potential therapeutic target.

\section{IL-10 Adjunct therapy}

Another cytokine essential for ameliorating the course of $S$. aureus induced arthritis is IL-10.This antiinflammatory cytokine has been shown to promote bacterial clearance and down-regulates cell mediated immune functions acting as an important immuneregulatory cytokin e[179, 180]. Study involved Balb/c mice (wild type as well as IL-10 gene deficient) that were inoculated with high dose of bacteria. IL-10 gene knockout mice developed a more severe and destructive course of infection with higher bacterial burden in associated organs i.e blood and kidneys when compared to wild type control group. This highlighted that recombinant IL-10 may have a beneficial effect on the treatment outcome and represents a possible adjunct to antibiotic treatment.

\section{IL-4 Blockage as possible Target}

Hultgren et al. [181] studied the role of IL-4, a Th2 cytokine in experimentally induced $S$. aureus septic arthritis in IL-4-deficient C57BL/6 mice (IL-4-/-) and their congenic controls $(\mathrm{IL}-4+/+)$ challenged with TSST-1 producing strains of $S$. aureus. The IL-4-/- mice showed reduced joint inflammation and also decreased bacterial load in joints and kidneys, lesser weight loss and lower mortality score as compared to the congenic controls. This highlighted the role of IL- 4 in promoting septic arthritis associated severity due to its inhibition of bacterial clearance during the $S$. aureus infection thus hinting towards use of IL-4 blockage as one of the treatment targets for ameliorating the disease pathology.

\section{Platelet-rich plasma (PRP) based treatment}

PRP is made by extracting donor's whole blood which can also be pooled for use as regenerative therapy to treat and manage various musculoskeletal conditions. However, recently PRP has gained attention to exhibit potent anti-biofilm effects as well. Pooled platelet rich plasma lysate (PRP-L) has been suggested as an alternative strategy to augment the current antimicrobial treatment against infectious arthritis since $S$. aureus and Staphylococcus epidermidis are capable of forming floating biofilm like aggregates in both human and bovine synovial fluid. This may be a strong evading mechanism adopted by these bacteria leading to relapse of the infection despite prolonged antibiotic therapy in septic arthritis. Recently, Gilbertie et al .[182] demonstrated the potential efficacy of PRP-L formulations against synovial fluid biofilm aggregates in an in vitro equine model of infectious arthritis. For this, equine synovial fluid was collected and infected with $S$. aureus. This led to biofilm like clumps or aggregates when incubated for a two hour period in the synovial fluid. This was followed by treatment of the infected synovial fluid with PRP formulations alone as well as with aminoglycoside. Results indicated that the PRP formulations displayed significant anti-biofilm properties with marked reduction in bacterial load and displayed synergism when given along with amikacin. Further, lysis of PRP and pooling of the PRP lysate (PRP-L) also exhibited higher anti-bacterial activity against $S$. aureus which strongly advocates its further exploration as a valuable therapeutic adjunct therapy.

Box-1: Other Recent Developments against SA

- Cho et al .1183] developed a novel treatment for end-stage pyogenic arthritis of the hip that consisted of developing antibiotic-loaded cement femoral head spacers. This technique was tested in 10 patients suffering from acute hip arthritis and significant joint destruction. Results demonstrated that the novel femoral head spacer technique showed promising outcomes as seen by decreased pain in the affected hip, better control of the infection with reduced burden of S. aureus and Streptococcus species with preserved proximal femoral bone and soft tissue tension thus overall improving the joint function and mobility in the treated patents.

- Hsu et al. [184] developed a novel electrosprayed multi

pharmaceutical-loaded Nanoparticle system for direct knee injections for treatment of native septic arthritis. The nanoparticles consisted of lidocaine, vancomycin, ceftazidime-eluting poly (D,L-lactide-co-glycolide) (PLGA). The biodegradable electrosprayed nano/microparticles released high concentrations of antibiotics into the synovial knee tissue of rabbits for more than 2 weeks which was well above the $\mathrm{MIC}_{90}$ for $S$. aureus. - Schulz et al. [185] reported the use of a novel diagnostic method termed the "Sepsis MetaScore" (SMS) which is an 11-mRNA host immune blood signature. This represents a rapid blood test that can distinguish between bacterial inflammation and non-infectious causes of inflammation thus directing correct treatment to be followed at the earliest. SMS also exhibited a higher degree of sensitivity and accuracy in diagnosing septic joints as compared to other diagnostic biomarkers (ESR, WBC and CRP) that do not help to provide information about bacterial induced or non-bacterial inflammation of the joints.

- Similarly, serum Procalcitonin levels (PCT) also represent a sensitive marker for differentiating between septic arthritis and non-septic arthritis [186]. A recent meta-analysis that consisted of 10 studies including 838 patients was aimed to study the usefulness of serum procalcitonin (PCT) as a potential diagnostic marker for correct detection of early septic arthritis (SA) Zhao et al. [187]. Study results indicated and advocated that serum PCT levels represent a sensitive and specific marker with higher diagnostic value than the classical CRP based test and was also to distinguish between SA from non-SA.

- Recently, Sultana and Bishayi [188] highlighted the potential use of a drug i.e etoposide that kills the monocyte/macrophage population as a useful adjunct therapy as tested in the mouse model of $S$. aureus induced SA. Mice were treated with etoposide given subcutaneously post bacterial inoculation. Results showed that the severity of arthritis was lower in the etoposide treated mice as monitored by the overall arthritis index, histopathological picture and decreased levels of proinflammatory cytokines, lower levels of reactive oxygen species and reduced levels of MMP-2.

\section{Conclusion}

$S$. aureus represents one of the problem pathogens frequently isolated from cases of septic arthritis and being associated with the highest treatment failure rates. To further worsen, there has been increased 
involvement of MRSA in cases of septic arthritis with higher rates of mortality than MSSA cases. Despite aggressive surgical procedure and long term antibiotic therapy, complete eradication of the pathogen may not occur leading to a chronic condition worsened with prolonged inflammation and subsequent irreversible joint issue damage. Moreover, depending upon the poor antibiotic susceptibility in case of treating resistant strains, clinical picture may turn towards need for amputation or may lead to life threatening situations such as sepsis. This calls for novel treatment modalities for acute and chronic SA effective even against the drugresistant strains and capable of down-regulating the deranged immune responses to decrease the tissue damage. The suggested non-antibiotic approaches against SA have shown promise in various in vitro and non-human model based studies. However, what is learned from laboratory or animal models cannot be applied to humans without undergoing sufficient randomised controlled trials after ethical approval. Nonetheless, the intervention strategies discussed in the review hold string potential to augment the standard antimicrobial protocols leading to decrease in the associated morbidity and mortality rates thus enabling to advance the treatment options for septic arthritis in near future.

\section{Abbreviations \\ MRSA: Methicillin resistant S. aureus; MSSA: Methicillin sensitive S. aureus; MMP: Matrix metalloproteinases; PCT: Pro-calcitonin; CRP: C- reactive protein; PRP: Platelet-rich plasma; CA-MRSA: Community acquired methicillin resistant S. aureus; HA-MRSA: Hospital acquired methicillin resistant S. aureus; SA: Septic arthritis; SF: Synovial fluid; TSST: Toxin shock syndrome toxin; DAIR: Debridement, antibiotics and implant retention; HBD: human $\beta$ - defensin}

\section{Acknowledgements}

Not applicable

\section{Authors' Contributions}

JW and LW : Literature search, Writing-Review and Editing. All authors have reviewed and approved the final version of the article, including the authorship list.

\section{Funding}

The authors declare that they have no funding sources.

\section{Availability of data and materials}

Not applicable

\section{Declarations}

Ethics approval and consent to participate

Not applicable

\section{Consent for publication}

Not applicable

\section{Competing interests}

The authors declare that they have no competing interests

\section{Author details}

1Department of Nursing, The Third Hospital of Jinan, Shandong Province, Jinan 250132, China. ${ }^{2}$ Hand and Foot Surgery, Shandong Provincial Hospital, Jinan 250000, China.

Received: 29 January 2021 Accepted: 18 May 2021

Published online: 09 June 2021

\section{References}

1. Smith JW, Chalupa P, Shabaz HM. Infectious arthritis: clinical features, laboratory findings and treatment. Clin Microbiol Infect. 2006;12(4):309-14. https://doi.org/10.1111/j.1469-0691.2006.01366.x.

2. Mathews CJ, Weston VC, Jones A, Field M, Coakley G. Bacterial septic arthritis in adults. Lancet. 2010;375:846-55.

3. Lynn MM, Mathews CJ. Advances in the management of bacterial septic arthritis. Int J Clin Rheumatol. 2012;7(3):335-42.

4. Abram SGF, Alvand A, Judge A, Beard DJ, Price AJ. Mortality and adverse joint outcomes following septic arthritis of the native knee: a longitudinal cohort study of patients receiving arthroscopic washout. Lancet Infect Dis. 2020;20(3):341-9. https://doi.org/10.1016/S1473-3099(19)30419-0.

5. Kwan Tat S, Padrines M, Théoleyre S, Heymann D, Fortun Y. IL-6, RANKL, TNF-alpha/LL-1: interrelations in bone resorption pathophysiology. Cytokine Growth Factor Rev. 2004;15(1):49-60. https://doi.org/10.1016/j.cytogfr.2003.1 0.005 .

6. Corrado A, Donato P, Maccari S, Cecchi R, Spadafina T, Arcidiacono L, et al. Staphylococcus aureus-dependent septic arthritis in murine knee joints: local immune response and beneficial effects of vaccination. Sci Rep. 2016;6: 38043. https://doi.org/10.1038/srep38043.

7. Mathews CJ, Kingsley G, Field M, et al. Management of septic arthritis: a systematic review. Ann Rheum Dis. 2007;66(4):440-5. https://doi.org/10.113 6/ard.2006.058909.

8. Miller A, Abduljabbar F, Jarzem P. Polyarticular Septic Arthritis in an Immunocompetent Adult: A Case Report and Review of the Literature. Case Rep Orthop. 2015;2015:602137. https://doi.org/10.1155/2015/602137.

9. Shirtliff ME, Mader JT. Acute septic arthritis. Clin Microbiol Rev. 2002;15(4): 527-44. https://doi.org/10.1128/cmr.15.4.527-544.2002.

10. Dubost JJ, Soubrier M, De Champs C, Ristori JM, Bussiére JL, Sauvezie B. No changes in the distribution of organisms responsible for septic arthritis over a 20 year period. Ann Rheum Dis. 2002;61(3):267-9. https://doi.org/10.113 6/ard.61.3.267.

11. Kaandorp CJ, Van Schaardenburg D, Krijnen P, Habbema JD, van de Laar MA. Risk factors for septic arthritis in patients with joint disease. A prospective study. Arthritis Rheum. 1995;38(12):1819-25. https://doi.org/10.1 002/art.1780381215.

12. Kherani RB, Shojania K. Septic arthritis in patients with pre-existing inflammatory arthritis [published correction appears in CMAJ. 2007;177(5): 489]. CMAJ. 2007;176(11):1605-8. https://doi.org/10.1503/cmaj.050258.

13. Elsissy JG, Liu JN, Wilton PJ, Nwachuku I, Gowd AK, Amin NH. Bacterial Septic Arthritis of the Adult Native Knee Joint: A Review. JBJS Rev. 2020;8(1): e0059. https://doi.org/10.2106/JBJS.RWW.19.00059.

14. Carpenter CR, Schuur JD, Everett WW, Pines JM. Evidence-based diagnostics: adult septic arthritis. Acad Emerg Med. 2011;18:781.

15. Costales C, Butler-Wu SM. A Real Pain: Diagnostic Quandaries and Septic Arthritis. J Clin Microbiol. 2018;56(2):e01358-17. https://doi.org/10.1128/JCM. 01358-17

16. Kaandorp CJ, Krijnen P, Moens HJ, Habbema JD, van Schaardenburg D. The outcome of bacterial arthritis: a prospective community-based study. Arthritis Rheum. 1997:40(5):884-92. https://doi.org/10.1002/art.1780400516.

17. Jung SW, Kim DH, Shin SJ, Kang BY, Eho YJ, Yang SW. Septic arthritis associated with systemic sepsis. Int Orthop. 2018;42(1):1-7. https://doi.org/1 0.1007/s00264-017-3565-4.

18. Al-Ahaideb A. Septic arthritis in patients with rheumatoid arthritis. J Orthop Surg Res. 2008:3:33. https://doi.org/10.1186/1749-799X-3-33.

19. Minguez S, Molinos S, Mateo L. Septic arthritis due to methicillin-resistant Staphylococcus aureus in adults. Reumatol Clin. 2015;11(NovemberDecember (6))::381-386

20. Ho G. Bacterial arthritis. Curr Opin Rheumatol. 2001;12:310-4.

21. Mathews CJ, Coakley G. Septic arthritis: current diagnostic and therapeutic algorithm. Curr Opin Rheumatol. 2008:20(4):457-62. https://doi.org/10.1097/ BOR.0b013e3283036975. 
22. Lidgren L. Septic arthritis and osteomyelitis. In: Hochberg MC, Silman AJ, Smolen JS, et al., editors. Rheumatology. Toronto: Mosby; 2003:1055-1066.

23. Nade S. Septic arthritis. Best Pract Res Clin Rheumatol. 2003;17(2):183-200. https://doi.org/10.1016/s1521-6942(02)00106-7.

24. Stoodley P, Ehrlich GD, Sedghizadeh PP, et al. Orthopaedic biofilm infections. Curr Orthop Pract. 2011;22(6):558-63. https://doi.org/10.1097/ BCO.0b013e318230efff.

25. Clerc O, Prod'hom G, Greub G, Zanetti G, Senn L. Adult native septic arthritis: a review of 10 years of experience and lessons for empirical antibiotic therapy. J Antimicrob Chemother. 2011;66(5):1168-73. https://doi. org/10.1093/jac/dkr047.

26. Okano T, Enokida M, Otsuki R, Hagino H, Teshima R. Recent trends in adultonset septic arthritis of the knee and hip: retrospective analysis of patients treated during the past 50 years. J Infect Chemother. 2011;17(5):666-70. https://doi.org/10.1007/s10156-011-0244-z.

27. Giannoudis PV, Parker J, Wilcox MH. Methicillin-resistant Staphylococcus aureus in trauma and orthopaedic practice. J Bone Joint Surg Br. 2005;87(6): 749-54. https://doi.org/10.1302/0301-620X.87B6.16292.

28. Patel A, Calfee RP, Plante M, Fischer SA, Arcand N, Born C. Methicillinresistant Staphylococcus aureus in orthopaedic surgery. J Bone Joint Surg Br. 2008;90(11):1401-6. https://doi.org/10.1302/0301-620X.90B11.20771.

29. Latha T, Anil B, Manjunatha H, Chiranjay M, Elsa D, Baby N, et al. MRSA: the leading pathogen of orthopedic infection in a tertiary care hospital, South India. Afr Health Sci. 2019;19(1):1393-401. https://doi.org/10.4314/ahs.v1 $9 i 1.12$.

30. Ross JJ, Davidson L. Methicillin-resistant Staphylococcus aureus septic arthritis: an emerging clinical syndrome. Rheumatology (Oxford). 2005;44(9): 1197-8. https://doi.org/10.1093/rheumatology/kei035.

31. Al-Nammari SS, Bobak P, Venkatesh R. Methicillin resistant Staphylococcus aureus versus methicillin sensitive Staphylococcus aureus adult haematogenous septic arthritis. Arch Orthop Trauma Surg. 2007;127(7):537-42.

32. Combs K, Cox K. Clinical outcomes involving patients that develop septic arthritis with methicillin sensitive Staphylococcus aureus versus methicillin resistant Staphylococcus aureus. J Orthop. 2017;15(1):9-12.

33. Herold BC, Immergluck LC, Maranan MC, Lauderdale DS, Gaskin RE, BoyleVavra S, et al. Community-acquired methicillin-resistant Staphylococcus aureus in children with no identified predisposing risk. JAMA. 1998;279(8): 593-8. https://doi.org/10.1001/jama.279.8.593.

34. Martínez-Aguilar G, Avalos-Mishaan A, Hulten K, Hammerman W, Mason EO Jr, Kaplan SL. Community-acquired, methicillin-resistant and methicillinsusceptible Staphylococcus aureus musculoskeletal infections in children. Pediatr Infect Dis J. 2004;23(8):701-6. https://doi.org/10.1097/01.inf.0000133 044.79130.2a.

35. Arnold SR, Elias D, Buckingham SC, Thomas ED, Novais E, Arkader A, et al. Changing patterns of acute hematogenous osteomyelitis and septic arthritis: emergence of community-associated methicillin-resistant Staphylococcus aureus. J Pediatr Orthop. 2006;26(6):703-8. https://doi.org/1 0.1097/01.bpo.0000242431.91489.b4

36. Naimi TS, LeDell KH, Como-Sabetti K, Borchardt SM, Boxrud DJ, Etienne J, et al. Comparison of community- and health care-associated methicillinresistant Staphylococcus aureus infection. JAMA. 2003;290(22):2976-84. https://doi.org/10.1001/jama.290.22.2976 PMID: 14665659.

37. Millar BC, Loughrey A, Elborn JS, Moore JE. Proposed definitions of community-associated meticillin-resistant Staphylococcus aureus (CA-MRSA). J Hosp Infect. 2007;67(2):109-13. https://doi.org/10.1016/j.jhin.2007.06.003.

38. Krieg AM. A possible cause of joint destruction in septic arthritis. Arthritis Res Ther. 1999:1:3.

39. Colavite PM, Sartori A. Septic arthritis: immunopathogenesis, experimental models and therapy. J Venom Anim Toxins Incl Trop Dis. 2014;20:19. https:// doi.org/10.1186/1678-9199-20-19.

40. Boff D, Crijns H, Teixeira MM, Amaral FA, Proost P. Neutrophils: Beneficial and Harmful Cells in Septic Arthritis. Int J Mol Sci. 2018;19(2):468. https://doi. org/10.3390/ijms19020468.

41. Garcia-De La Torre I. Advances in the management of septic arthritis. Rheum Dis Clin North Am. 2003;29(1):61-75. https://doi.org/10.1016/s0889857x(02)00080-7.

42. Long B, Koyfman A, Gottlieb M. Evaluation and Management of Septic Arthritis and its Mimics in the Emergency Department. West J Emerg Med. 2019;20(2):331-41. https://doi.org/10.5811/westjem.2018.10.40974.

43. Ross K, Mehr J, Carothers B, Greeley R, Benowitz I, McHugh L, et al. Outbreak of septic arthritis associated with intra-articular injections at an outpatient practice - New Jersey, 2017. MMWR Morb Mortal Wkly Rep. 2017;66(29):7779. https://doi.org/10.15585/mmwr.mm6629a3.

44. Tarkowski A. Infection and musculoskeletal conditions: Infectious arthritis. Best Pract Res Clin Rheumatol. 2006;20(6):1029-44. https://doi.org/10.1016/j. berh.2006.08.001.

45. Haywood L, Walsh DA. Vasculature of the normal and arthritic synovial joint. Histol Histopathol. 2001;16:277-84.

46. Goldenberg DL. Septic arthritis. Lancet. 1998;351(9097):197-202. https://doi. org/10.1016/S0140-6736(97)09522-6.

47. Hasan S, Smith JW. Septic arthritis. Curr Treat Options Infect Dis. 2001;3:279-86

48. Horst SA, Hoerr V, Beineke A, Kreis C, Tuchscherr L, Kalinka J, et al. A novel mouse model of Staphylococcus aureus chronic osteomyelitis that closely mimics the human infection: an integrated view of disease pathogenesis. Am J Pathol. 2012;181(4):1206-14. https://doi.org/10.1016/j.ajpath.2012.07. 005.

49. Foster TJ, Geoghegan JA, Ganesh VK, Hook M. Adhesion, invasion and evasion: the many functions of the surface proteins of Staphylococcus aureus. Nat Rev Microbiol. 2014;12:49-62. https://doi.org/10.1038/nrmicro3161.

50. Arciola CR, Campoccia D, Ehrlich GD, Montanaro L. Biofilm-based implant infections in orthopaedics. Adv Exp Med Biol. 2015;830:29-46.

51. Kim M, Zhao A, Wang A et al. 2017.Surface-attached molecules control Staphylococcus aureus quorum sensing and biofilm development. Nat Microbiol 2, 17080. https://doi.org/https://doi.org/10.1038/nmicrobiol.2017.80

52. Biswas R, Voggu L, Simon UK, Hentschel P, Thumm G, Gotz F. Activity of the major staphylococcal autolysin Atl. FEMS Microbiol Lett. 2006;259:260-8.

53. Campoccia D, Speziale P, Ravaioli S, et al. The presence of both bone sialoprotein-binding protein gene and collagen adhesin gene as a typical virulence trait of the major epidemic cluster in isolates from orthopedic implant infections. Biomaterials. 2009;30:6621-8. https://doi.org/10.1016/j. biomaterials.2009.08.032.

54. Switalski LM, Butcher WG, Caufield PC, Lantz MS. Collagen mediates adhesion of Streptococcus mutans to human dentin. Infect Immun. 1993;61: 4119-25.

55. Ryding U, Flock J, Flock M, Soderquist B, Christensson B. Expression of collagen-binding protein and types 5 and 8 capsular polysaccharide in clinical isolates of Staphylococcus aureus. J Infect Dis. 1997;176:1096-9.

56. Nilsson IM, Hartford O, Foster T, Tarkowski A. Alpha-toxin and gamma-toxin jointly promote Staphylococcus aureus virulence in murine septic arthritis. Infect. Immun. 1999;67:1045-9.

57. Perez K, Patel R. Survival of Staphylococcus epidermidis in Fibroblasts and Osteoblasts. Infect Immun. 2018;86(10):e00237-18. https://doi.org/10.1128/IA I.00237-18.

58. Dastgheyb S, Parvizi J, Shapiro IM, Hickok NJ, Otto M. Effect of biofilms on recalcitrance of staphylococcal joint infection to antibiotic treatment. J Infect Dis. 2015;211(4):641-50. https://doi.org/10.1093/infdis/jiu514.

59. Gilbertie JM, Schaer TP, Schubert AG, Jacob ME, Menegatti S, Ashton Lavoie $R$, et al. Platelet-rich plasma lysate displays anti-biofilm properties and restores antimicrobial activity against synovial fluid biofilms in vitro. J Orthop Res. 2020;38(6):1365-74. https://doi.org/10.1002/jor.24584.

60. Pestrak MJ, Gupta TT, Dusane DH, et al. Investigation of synovial fluid induced Staphylococcus aureus aggregate development and its impact on surface attachment and biofilm formation [published correction appears in PLoS One. 2020 May 14;15(5):e0233534]. PLoS One. 2020;15(4):e0231791. https://doi.org/10.1371/journal.pone.0231791.

61. Sendi P, Rohrbach M, Graber P, Frei R, Ochsner PE, Zimmerli W. Staphylococcus aureus small colony variants in prosthetic joint infection. Clin Infect Dis. 2006;43(8):961-7.

62. McConoughey SJ, Howlin R, Granger JF, et al. Biofilms in periprosthetic orthopedic infections [published correction appears in Future Microbiol. 2014; 9(10):1234]. Future Microbiol. 2014;9(8):987-1007.

63. Proctor RA, Kriegeskorte A, Kahl BC, Becker K, Löffler B, Peters G. Staphylococcus aureus Small Colony Variants (SCVs): a road map for the metabolic pathways involved in persistent infections. Front Cell Infect Microbiol. 2014:4:99. https://doi.org/10.3389/fcimb.2014.00099.

64. Kahl BC, Becker K, Loffler B. Clinical significance and pathogenesis of staphylococcal small colony variants in persistent infections. Clin. Microbiol. Rev. 2016;29:401-27. https://doi.org/10.1128/CMR.00069-15.

65. Moriarty TF, Kuehl R, Coenye T, et al. Orthopaedic device-related infection: current and future interventions for improved prevention and treatment. EFORT Open Rev. 2016;1(4):89-99. https://doi.org/10.1302/2058-5241.1.00003 7. 
66. Josse J, Valour F, Maali Y, et al. Interaction Between Staphylococcal Biofilm and Bone: How Does the Presence of Biofilm Promote Prosthesis Loosening? Front Microbiol. 2019;10:1602. https://doi.org/10.3389/fmicb.2019.01602.

67. Abdelnour A, Bremell T, Holmdahl R, Tarkowski A. Clonal expansion of T lymphocytes causes arthritis and mortality in mice infected with toxic shock syndrome toxin-1-producing staphylococci. Eur J Immunol. 1994;24(5):11616. https://doi.org/10.1002/eji.1830240523.

68. Colavite-Machado PM, Ishikawa LL, França TG, Zorzella-Pezavento SF, da Rosa LC, Chiuso-Minicucci F, et al. Differential arthritogenicity of Staphylococcus aureus strains isolated from biological samples. BMC Infect Dis. 2013;13:400. https://doi.org/10.1186/1471-2334-13-400.

69. Smith IDM, Milto KM, Doherty CJ, Amyes SGB, Simpson AHRW, Hall AC. A potential key role for alpha-haemolysin of Staphylococcus aureus in mediating chondrocyte death in septic arthritis. Bone Joint Res. 2018;7(7): 457-67. https://doi.org/10.1302/2046-3758.77.BJR-2017-0165.R1.

70. Dohin B, Gillet $Y$, Kohler R, Lina G, Vandenesch F, Vanhems P, et al. Pediatric bone and joint infections caused by Panton-Valentine leukocidin-positive Staphylococcus aureus. Pediatr Infect Dis J. 2007;26(11):1042-8. https://doi. org/10.1097/INF.0b013e318133a85e.

71. Crémieux AC, Dumitrescu O, Lina G, Vallee C, Côté JF, Muffat-Joly M, et al. Panton-valentine leukocidin enhances the severity of community-associated methicillin-resistant Staphylococcus aureus rabbit osteomyelitis. PLoS One. 2009;4(9):e7204. https://doi.org/10.1371/journal.pone.0007204.

72. Dodwell ER. Osteomyelitis and septic arthritis in children: current concepts. Curr Opin Pediatr. 2013;25(1):58-63.

73. Janssens S, Beyaert R. Role of Toll-like receptors in pathogen recognition. Clin Microbiol Rev. 2003;16(4):637-46. https://doi.org/10.1128/cmr.16.4.637646.2003.

74. Papathanasiou I, Malizos KN, Poultsides L. The catabolic role of toll-like receptor 2 (TLR-2) mediated by the NF-kB pathway in septic arthritis. $J$ Orthop Res. 2011;29(2):247-51.

75. Oliveira-Nascimento L, Massari P, Wetzler LM. The role of TLR2 in infection and immunity. Front Immun. 2012;3:79. https://doi.org/10.3389/fimmu.2012. 00079.

76. Bremell T, Tarkowski A. Preferential induction of septic arthritis and mortality by superantigen-producing staphylococci. Infect. Immun. 1995;63:4185-7.

77. Tarkowski A, Bokarewa M, Collins LV, Gjertsson I, Hultgren OH, Jin T, et al. Current status of pathogenetic mechanisms in staphylococcal arthritis. FEMS Microbiol Letters. 2002;217:125-32.

78. Kanangat S, Postlethwaite A, Hasty $\mathrm{K}$, et al. Induction of multiple matrix metalloproteinases in human dermal and synovial fibroblasts by Staphylococcus aureus: implications in the pathogenesis of septic arthritis and other soft tissue infections. Arthritis Res Ther. 2006;8(6):R176. https://doi. org/10.1186/ar2086.

79. Nair R, Schweizer ML, Singh N. Septic Arthritis and Prosthetic Joint Infections in Older Adults. Infect Dis Clin North Am. 2017;31(4):715-29. https://doi.org/10.1016/j.idc.2017.07.013.

80. Mitchell M, Howard B, Haller J, Sartoris DJ, Resnick D. Septic arthritis. Radiol. Clin. North Am. 1988;26:1295-313.

81. Diamond G, Beckloff N, Weinberg A, Kisich KO. The roles of antimicrobial peptides in innate host defense. Curr Pharm Des. 2009;15(21):2377-92. https://doi.org/10.2174/138161209788682325 .

82. Pasupuleti M, Schmidtchen A, Malmsten M. Antimicrobial peptides: key components of the innate immune system. Crit Rev Biotechnol. 2012;32(2): 143-71. https://doi.org/10.3109/07388551.2011.594423.

83. Riool M, de Breij A, Drijfhout JW, Nibbering PH, Zaat SAJ. Antimicrobial Peptides in Biomedical Device Manufacturing. Front Chem. 2017;5:63.

84. Mwangi J, Hao X, Lai R, Zhang ZY. Antimicrobial peptides: new hope in the war against multidrug resistance. Zool Res. 2019;40(6):488-505. https://doi. org/10.24272/j.issn.2095-8137.2019.062.

85. Bahar AA, Ren D. Antimicrobial peptides. Pharmaceuticals (Basel). 2013;6(12): 1543-75. https://doi.org/10.3390/ph6121543.

86. Moravej H, Moravej Z, Yazdanparast M, Heiat M, Mirhosseini A, Moosazadeh Moghaddam M, et al. Antimicrobial peptides: features, action, and their resistance mechanisms in bacteria. Microb Drug Resist. 2018;24(6):747-67. https://doi.org/10.1089/mdr.2017.0392.

87. Lei J, Sun L, Huang S, et al. The antimicrobial peptides and their potential clinical applications. Am J Transl Res. 2019;11(7):3919-31.

88. Nguyen LT, Haney EF, Vogel HJ. The expanding scope of antimicrobial peptide structures and their modes of action. 2011;29:464-72. https://doi. org/10.1016/j.tibtech.2011.05.001.
89. Guilhelmelli F, Vilela N, Albuquerque P, Derengowski Lda S, Silva-Pereira I, Kyaw CM. Antibiotic development challenges: the various mechanisms of action of antimicrobial peptides and of bacterial resistance. Front Microbiol. 2013;4:353. https://doi.org/10.3389/fmicb.2013.00353.

90. Le CF, Fang CM, Sekaran SD. Intracellular Targeting Mechanisms by Antimicrobial Peptides. Antimicrob Agents Chemother. 2017;61(4):e0234016. https://doi.org/10.1128/AAC.02340-16.

91. Hancock RE, Sahl HG. Antimicrobial and host-defense peptides as new antiinfective therapeutic strategies. Nat. Biotechnol. 2006;24:1551-7. https://doi. org/10.1038/nbt1267.

92. Mahlapuu M, Hakansson J, Ringstad L, Björn C. Antimicrobial peptides: an emerging category of therapeutic agents. Front Cell Infect Microbiol. 2016;6: 194.

93. Kang HK, Lee $\mathrm{HH}$, Seo CH, Park Y. Antimicrobial and immunomodulatory properties and applications of marine-derived proteins and peptides. Mar Drugs. 2019;17(6):350. https://doi.org/10.3390/md17060350.

94. Yang D, Chertov O, Bykovskaia SN, Chen Q, Buffo MJ, Shogan J, et al. Betadefensins: linking innate and adaptive immunity through dendritic and T cell CCR6. Science. 1999;286(5439):525-8. https://doi.org/10.1126/science.2 86.5439 .525

95. Tjabringa GS, Aarbiou J, Ninaber DK, Drijfhout JW, Sørensen OE, Borregaard $\mathrm{N}$, et al. The antimicrobial peptide LL-37 activates innate immunity at the airway epithelial surface by transactivation of the epidermal growth factor receptor. J Immunol. 2003;171(12):6690-6. https://doi.org/10.4049/ jimmunol.171.12.6690

96. Agier J, Efenberger M, Brzezińska-Błaszczyk E. Cathelicidin impact on inflammatory cells. Cent Eur J Immunol. 2015;40(2):225-35. https://doi.org/1 0.5114/ceji.2015.51359.

97. Mookherjee N, Brown KL, Bowdish DM, Doria S, Falsafi R, Hokamp K, et al. Modulation of the TLR-mediated inflammatory response by the endogenous human host defense peptide LL-37. J Immunol. 2006;176(4): 2455-64. https://doi.org/10.4049/jimmunol.176.4.2455.

98. Ganguly D, Chamilos G, Lande R, Gregorio J, Meller S, Facchinetti V, et al. Self-RNA-antimicrobial peptide complexes activate human dendritic cells through TLR7 and TLR8. J Exp Med. 2009;206(9):1983-94. https://doi.org/10.1 084/jem.20090480.

99. Liang W, Diana J. The Dual Role of Antimicrobial Peptides in Autoimmunity. Front Immunol. 2020;11:2077. https://doi.org/10.3389/fimmu.2020.02077.

100. Mattsby-Baltzer I, Roseanu A, Motas C, Elverfors J, Engberg I, Hanson LA. Lactoferrin or a fragment thereof inhibits the endotoxin-induced interleukin-6 response in human monocytic cells. Pediatr. Res. 1996;40:25762. https://doi.org/10.1203/00006450-199608000-00011.

101. Bowdish DM, Davidson DJ, Scott MG, Hancock RE. Immunomodulatory activities of small host defense peptides. Antimicrob Agents Chemother 2005:49(5):1727-32. https://doi.org/10.1128/AAC.49.5.1727-1732.2005.

102. Wu BC, Lee AH, Hancock REW. Mechanisms of the innate defense regulator peptide-1002 anti-inflammatory activity in a sterile inflammation mouse model. J Immunol. 2017;199(10):3592-603. https://doi.org/10.4049/ jimmunol.1700985.

103. Levast B, Hogan D, van Kessel J, et al. synthetic cationic peptide idr-1002 and human cathelicidin II37 modulate the cell innate response but differentially impact PRRSV replication in vitro. Front Vet Sci. 2019;6:233. https://doi.org/10.3389/fvets.2019.00233.

104. Lai Y, Gallo RL. AMPed up immunity: how antimicrobial peptides have multiple roles in immune defense. Trends Immunol. 2009;30(3):131-41. https://doi.org/10.1016/j.it.2008.12.003.

105. Shao C, Li W, Tan P, Shan A, Dou X, Ma D, et al. Symmetrical modification of minimized dermaseptins to extend the spectrum of antimicrobials with endotoxin neutralization potency. Int J Mol Sci. 2019;20(6):1417. https://doi. org/10.3390/ijms20061417.

106. Reffuveille F, de la Fuente-Núñez C, Mansour S, Hancock RE. A broadspectrum antibiofilm peptide enhances antibiotic action against bacterial biofilms. Antimicrob Agents Chemother. 2014;58(9):5363-71.

107. Lewies A, Du Plessis LH, Wentzel JF. Antimicrobial peptides: the achilles' heel of antibiotic resistance? Probiot. Antimicrob. Proteins. 2018;11:370-81. https://doi.org/10.1007/s12602-018-9465-0.

108. Varoga D, Klostermeier E, Paulsen F, Wruck C, Lippross S, Brandenburg $\mathrm{LO}$, et al. The antimicrobial peptide HBD-2 and the Toll-like receptors-2 and -4 are induced in synovial membranes in case of septic arthritis. Virchows Arch. 2009:454(6):685-94. https://doi.org/10.1007/s00428-0090780-4. 
109. Paulsen F, Pufe T, Conradi L, et al. Antimicrobial peptides are expressed and produced in healthy and inflamed human synovial membranes. J Pathol. 2002;198:369-77.

110. Paulsen F, Pufe T, Petersen W, Tillmann B. Expression of natural peptide antibiotics in human articular cartilage and synovial membrane. Clin Diagn Lab Immunol. 2001:8:1021-3.

111. Elezagic D, Mörgelin M, Hermes G, Hamprecht A, Sengle G, Lau D, et al. Antimicrobial peptides derived from the cartilage.-specific C-type lectin domain family 3 member A (CLEC3A) - potential in the prevention and treatment of septic arthritis. Osteoarthritis Cartilage. 2019;27(10):1564-73. https://doi.org/10.1016/j.joca.2019.06.007.

112. Reis PVM, Boff D, Verly RM, Melo-Braga MN, Cortés ME, Santos DM, et al. LyeTxI-b, a synthetic peptide derived from lycosa erythrognatha spider venom, shows potent antibiotic activity in Vitro and in Vivo. Front Microbiol. 2018:9:667. https://doi.org/10.3389/fmicb.2018.00667.

113. Yazici H, O'Neill MB, Kacar T, et al. Engineered Chimeric Peptides as Antimicrobial Surface Coating Agents toward Infection-Free Implants. ACS Appl Mater Interfaces. 2016;8(8):5070-81.

114. de Breij A, Riool M, Kwakman PH, et al. Prevention of Staphylococcus aureus biomaterial-associated infections using a polymer-lipid coating containing the antimicrobial peptide OP-145. J Control Release. 2016;222:1-8.

115. Bormann N, Koliszak A, Kasper S, Schoen L, Hilpert K, Volkmer R, et al. A short artificial antimicrobial peptide shows potential to prevent or treat bone infections. Sci Rep. 2017;7(1):1506. https://doi.org/10.1038/s41598-01701698-0.

116. Almaaytah A, Mohammed GK, Abualhaijaa A, Al-Balas Q. Development of novel ultrashort antimicrobial peptide nanoparticles with potent antimicrobial and antibiofilm activities against multidrug-resistant bacteria. Drug Des Devel Ther. 2017;11:3159-70. https://doi.org/10.2147/DDDT.S1474 50.

117. Kang J, Dietz MJ, Li B. 2019.Antimicrobial peptide LL-37 is bactericidal against Staphylococcus aureus biofilms. PLoS One. 14(6):e0216676.

118. Chen J, Shi X, Zhu Y, et al. On-demand storage and release of antimicrobial peptides using Pandora's box-like nanotubes gated with a bacterial infection-responsive polymer. Theranostics. 2020;10(1):109-22.

119. Lee HR, You DG, Kim HK, Sohn JW, Kim MJ, Park JK, et al. Romo1-derived antimicrobial peptide is a new antimicrobial agent against multidrugresistant bacteria in a murine model of sepsis. mBio. 2020;11(2):e03258-19. https://doi.org/10.1128/mBio.03258-19.

120. Duckworth D, Gulig P. Bacteriophage: potential treatment for bacterial infections. Biodrugs. 2002;16:57-62.

121. Azeredo J, Sutherland IW. The use of phages for the removal of infectious biofilms. Curr Pharm Biotechnol. 2008;9:261-6.

122. Sulakvelidze A, Alavidze Z, Morris JG Jr. Bacteriophage therapy. Antimicrob Agents Chemother. 2001;45(3):649-59. https://doi.org/10.1128/AAC.45.3.649659.2001.

123. Kutateladze M, Adamia R. Bacteriophages as potential new therapeutics to replace or supplement antibiotics. Trends Biotechnol. 2010;28:591-5.

124. Bedi MS, Verma V, Chhibber S. Amoxicillin and specific bacteriophage can be used together for eradication of biofilm of Klebsiella pneumoniae B5055. World J Microbiol Biotechnol. 2009;25:1145-51.

125. Chhibber S, Kaur T, Kaur S. Co-therapy using lytic bacteriophage and linezolid: effective treatment in eliminating methicillin resistant Staphylococcus aureus (MRSA) from diabetic foot infections. PLoS One. 2013; 8(2):e56022. https://doi.org/10.1371/journal.pone.0056022.

126. Kaur S, Harjai K, Chhibber S. In vivo assessment of phage and linezolid based implant coatings for treatment of methicillin resistant S. aureus (MRSA) mediated orthopaedic device related infections. PLoS One. 2016; 11(6):e0157626.

127. Bragg R, van der Westhuizen W, Lee JY, Coetsee E, Boucher C. Bacteriophages as potential treatment option for antibiotic resistant bacteria. Adv Exp Med Biol. 2014;807:97-110. https://doi.org/10.1007/97881-322-1777-0 7.

128. Luong T, Salabarria AC, Roach DR. Phage Therapy in the Resistance Era: Where Do We Stand and Where Are We Going? Clin Ther. 2020;42(9):165980. https://doi.org/10.1016/j.clinthera.2020.07.014.

129. Taati MM, Khoshbayan A, Chegini Z, Farahani I, Shariati A. Bacteriophages, a new therapeutic solution for inhibiting multidrug-resistant bacteria causing wound infection: lesson from animal models and clinical trials. Drug Des Devel Ther. 2020;14:1867-83.
130. Fong SA, Drilling A, Morales S, et al. Activity of Bacteriophages in Removing Biofilms of Pseudomonas aeruginosa Isolates from Chronic Rhinosinusitis Patients. Front Cell Infect Microbiol. 2017;7:418. https://doi.org/10.3389/ fcimb.2017.00418.

131. Ferriol-González C, Domingo-Calap P. Phages for Biofilm Removal. Antibiotics. 2020;9:268

132. Drulis-Kawa Z, Majkowska-Skrobek G, Maciejewska B. Bacteriophages and phage-derived proteins--application approaches. Curr Med Chem. 2015; 22(14):1757-73. https://doi.org/10.2174/0929867322666150209152851.

133. Abedon ST. Ecology of anti-biofilm agents II: bacteriophage exploitation and biocontrol of biofilm bacteria. Pharmaceuticals. 2015;8:559-89.

134. Maciejewska B, Olszak T, Drulis-Kawa Z. Applications of bacteriophages versus phage enzymes to combat and cure bacterial infections: an ambitious and also a realistic application? Appl Microbiol Biotechnol. 2018; 102(6):2563-81.

135. Loss G, Simões PM, Valour F, et al. Staphylococcus aureus Small Colony Variants (SCVs): News from a Chronic Prosthetic Joint Infection. Front Cell Infect Microbiol. 2019;9:363. https://doi.org/10.3389/fcimb.2019.00363.

136. Jevon M, Guo C, Ma B, Mordan N, Nair SP, Harris M, et al. Mechanisms of internalization of Staphylococcus aureus by cultured human osteoblasts. Infect Immun. 1999:67:2677-81.

137. Ellington JK, Reilly SS, Ramp WK, Smeltzer MS, Kellam JF, Hudson MC. Mechanisms of Staphylococcus aureus invasion of cultured osteoblasts. Microb Pathog. 1999;26:317-23.

138. Garzoni C, Kelley WL. Staphylococcus aureus : new evidence for intracellular persistence. Trends Microbiol. 2009;17:59-65.

139. Shi S, Zhang X. Interaction of Staphylococcus aureus with osteoblasts (Review). Exp Ther Med. 2012;3(3):367-70. https://doi.org/10.3892/etm.2 011.423.

140. Perez K, Patel R. Survival of Staphylococcus epidermidis in Fibroblasts and Osteoblasts. Infect Immun. 2018;86(10):e00237-18. https://doi.org/10.1128/IA 1.00237-18.

141. Zhang L, Sun L, Wei R, et al. Intracellular Staphylococcus aureus Control by Virulent Bacteriophages within MAC-T Bovine Mammary Epithelial Cells. Antimicrob Agents Chemother. 2017;61(2):e01990-16.

142. Przerwa A, Zimecki M, Switała-Jeleń $K$, et al. Effects of bacteriophages on free radical production and phagocytic functions. Med Microbiol Immunol. 2006;195(3):143-50. https://doi.org/10.1007/s00430-006-0011-4.

143. Borysowski J, Wierzbicki P, Kłosowska D, Korczak-Kowalska G, WeberDąbrowska B, Gorski A. The effects of T4 and A3/R phage preparations on whole-blood monocyte and neutrophil respiratory bursts. Viral Immunol. 2010:541-4. https://doi.org/10.1089/vim.2010.0001.

144. Górski A, Międzybrodzki R, Borysowski J, Dąbrowska K, Wierzbicki P, et al. Phage as a modulator of immune responses. Practical implications for phage therapy. Adv Virus Res. 2012;83:41-71. https://doi.org/10.1016/B9780-12-394438-2.00002-5.

145. Górski A, Dąbrowska K, Międzybrodzki R, et al. Phages and immunomodulation. Future Microbiol. 2017;12:905-14. https://doi.org/1 0.2217/fmb-2017-0049.

146. Pabary R, Singh C, Morales S, et al. Anti-pseudomonal bacteriophage reduces infective burden and inflammatory response in murine lung. Antimicrob Agents Chemother. 2015;60(2):744-51. https://doi.org/10.112 8/AAC.01426-15.

147. Van Belleghem JD, Clement F, Merabishvili M, Lavigne R, Vaneechoutte M. Pro-and anti-inflammatory responses of peripheral blood mononuclear cells induced by Staphylococcus aureus and Pseudomonas aeruginosa phages. Sci Rep. 2017:7(1):1-13.

148. Gorski A, Kniotek M, Perkowska-Ptasińska A, et al. Bacteriophages and transplantation tolerance. Transplant Proc. 2006;38(1):331-3. https://doi. org/10.1016/j.transproceed.2005.12.073.

149. Hashiguchi S, Yamaguchi Y, Takeuchi O, Akira S, Sugimura K. Immunological basis of M13 phage vaccine: Regulation under MyD88 and TLR9 signalling. Biochem Biophys Res Commun. 2010;402(1):19-22. https://doi.org/10.1016/j. bbrc.2010.09.094.

150. Zhang L, Hou X, Sun L, et al. Staphylococcus aureus bacteriophage suppresses LPS-Induced Inflammation in MAC-T bovine mammary epithelial cells [published correction appears in Front Microbiol. 2018 9;9:2511]. Front Microbiol. 2018:9:1614. https://doi.org/10.3389/fmicb.2018.01614.

151. Morris $J$, Letson HL, Elliott L, Grant AL, Wilkinson M, Hazratwala K, et al. Evaluation of bacteriophage as an adjunct therapy for treatment of peri- 
prosthetic joint infection caused by Staphylococcus aureus. PLoS One. 2019; 14(12):e0226574. https://doi.org/10.1371/journal.pone.0226574.

152. Kishor C, Mishra RR, Saraf SK, Kumar M, Srivastav AK, Nath G. Phage therapy of staphylococcal chronic osteomyelitis in experimental animal model. Indian J Med Res. 2016;143(1):87-94.

153. Doub JB, Ng VY, Johnson AJ, Slomka M, Fackler J, Horne B, et al. Salvage Bacteriophage Therapy for a Chronic MRSA Prosthetic Joint Infection. Antibiotics (Basel). 2020;9(5):241. https://doi.org/10.3390/antibiotics9050241.

154. Nir-Paz R, Gelman D, Khouri A, Sisson BM, Fackler J, Alkalay-Oren S, et al. Successful Treatment of Antibiotic-resistant, Poly-microbial Bone Infection with Bacteriophages and Antibiotics Combination. Clin Infect Dis. 2019; 69(11):2015-8. https://doi.org/10.1093/cid/ciz222.

155. Kodumuri P, Geutjens G, Kerr HL. Time delay between diagnosis and arthroscopic lavage in septic arthritis. Does it matter? Int Orthop. 2012;36(8): 1727-31. https://doi.org/10.1007/s00264-012-1546-1.

156. Davis CM, Zamora RA. Surgical Options and Approaches for Septic Arthritis of the Native Hip and Knee Joint. J Arthroplasty. 2020;35(3S):S14-8. https:// doi.org/10.1016/j.arth.2019.10.062.

157. Watanabe R, Matsumoto T, Sano G, et al. Efficacy of bacteriophage therapy against gut-derived sepsis caused by Pseudomonas aeruginosa in mice. Antimicrob Agents Chemother. 2007;51(2):446-52. https://doi.org/10.112 8/AAC.00635-06.

158. Kim KP, Cha JD, Jang EH, et al. PEGylation of bacteriophages increases blood circulation time and reduces T-helper type 1 immune response. Microb Biotechnol. 2008;1(3):247-57. https://doi.org/10.1111/j.1751-7915.2 008.00028.x.

159. Chanishvili N. Phage therapy-history from Twort and d'Herelle through Soviet experience to current approaches. Adv Virus Res. 2012;83:3-40. https://doi.org/10.1016/B978-0-12-394438-2.00001-3.

160. Schooley RT, Biswas B, Gill JJ, Hernandez-Morales A, Lancaster J, Lessor L, et al. Development and use of personalized bacteriophage-based therapeutic cocktails to treat a patient with a disseminated resistant Acinetobacter baumannii Infection. Antimicrob Agents Chemother. 2017; 61(10):e00954-17. https://doi.org/10.1128/AAC.00954-17.

161. Ferry T, Batailler C, Petitjean C, Chateau J, Fevre C, Forestier E, et al. The potential innovative use of bacteriophages within the DAC ${ }^{\oplus}$ hydrogel to treat patients with knee megaprosthesis infection requiring "debridement antibiotics and implant retention" and soft tissue coverage as salvage therapy. Front Med (Lausanne). 2020;7:342. https://doi.org/10.3389/fmed.202 0.00342 .

162. Markoishvili K, Tsitlanadze G, Katsarava R, Morris JG Jr, Sulakvelidze A. A novel sustained-release matrix based on biodegradable poly (ester amide) $\mathrm{s}$ and impregnated with bacteriophages and an antibiotic shows promise in management of infected venous stasis ulcers and other poorly healing wounds. Int J Dermatol. 2002;41(7):453-8. https://doi.org/10.1046/j.1365-43 62.2002.01451.X PMID: 12121566.

163. Jikia D, Chkhaidze N, Imedashvili E, Mgaloblishvili I, Tsitlanadze G, Katsarava $R$, et al. The use of a novel biodegradable preparation capable of the sustained release of bacteriophages and ciprofloxacin, in the complex treatment of multidrug-resistant Staphylococcus aureus-infected local radiation injuries caused by exposure to Sr90. Clin Exp Dermatol. 2005;30: 23-6. https://doi.org/10.1111/j.1365-2230.2004.01600.

164. Duplessis C, Biswas B, Hanisch B, Perkins M, Henry M, Quinones J, et al. Refractory Pseudomonas Bacteremia in a 2-Year-Old Sterilized by Bacteriophage Therapy. J Pediatric Infect Dis Soc. 2018;7(3):253-6. https:// doi.org/10.1093/jpids/pix056

165. Jennes S, Merabishvili M, Soentjens P, Pang KW, Rose T, Keersebilck E, et al. Use of bacteriophages in the treatment of colistin-only-sensitive Pseudomonas aeruginosa septicaemia in a patient with acute kidney injury-a case report. Crit Care. 2017;21(1):129. https://doi.org/10.1186/s13054-017-1 709-y.

166. Fotopoulos VC, Tzinia A, Tzurbakis M, Kalfakakou V, Levidiotou-Stefanou S, Georgoulis A. Expression levels of matrix metalloproteinase (MMP)-9 and its specific inhibitor TIMP-1, in septic and aseptic arthritis of the knee. Knee Surg Sports Traumatol Arthrosc. 2012;20(6):1159-67. https://doi.org/10.1007/ s00167-011-1676-9.

167. Sultana S, Adhikary R, Nandi A, Bishayi B. Neutralization of MMP-2 protects Staphylococcus aureus infection induced septic arthritis in mice and regulates the levels of cytokines. Microb Pathog. 2016;99:148-61. https://doi. org/10.1016/j.micpath.2016.08.021.
168. Yoshihara Y, Nakamura H, Obata K, Yamada H, Hayakawa T, Fujikawa K, et al. Matrix metalloproteinases and tissue inhibitors of metalloproteinases in synovial fluids from patients with rheumatoid arthritis or osteoarthritis. Ann Rheum Dis. 2000;59:455.

169. Burrage PS, Mix KS, Brinckerhoff CE. Matrix metalloproteinases: role in arthritis. Front Biosci. 2006;11:529-43. https://doi.org/10.2741/1817 PMID: 16146751.

170. Calander AM, Starckx S, Opdenakker G, Bergin P, Quiding-Järbrink M, Tarkowski A. Matrix metalloproteinase-9 (gelatinase B) deficiency leads to increased severity of Staphylococcus aureus-triggered septic arthritis. Microbes Infect. 2006;8(6):1434-9. https://doi.org/10.1016/j.micinf.2006.01. 001.

171. Puliti M, Momi S, Falcinelli E, Gresele P, Bistoni F, Tissi L. Contribution of matrix metalloproteinase 2 to joint destruction in group B Streptococcusinduced murine arthritis. Arthritis Rheum. 2012;64(4):1089-97. https://doi. org/10.1002/art.33450.

172. Han YP, Tuan TL, Wu H, Hughes M, Garner WL. TNF-alpha stimulates activation of pro-MMP2 in human skin through NF-(kappa) B mediated induction of MT1-MMP. J Cell Sci. 2001;114(Pt 1):131-9.

173. Kanangat S, Postlethwaite A, Hasty K, et al. Induction of multiple matrix metalloproteinases in human dermal and synovial fibroblasts by Staphylococcus aureus: implications in the pathogenesis of septic arthritis and other soft tissue infections. Arthritis Res Ther. 2006;8(6):R176. https://doi. org/10.1186/ar2086.

174. Sultana S, Dey R, Bishayi B. Dual neutralization of TNFR-2 and MMP-2 regulates the severity of $S$. aureus induced septic arthritis correlating alteration in the level of interferon gamma and interleukin-10 in terms of TNFR2 blocking. Immunol Res. 2018;66(1):97-119. https://doi.org/10.1007/ s12026-017-8979-y.

175. Gjertsson I, Innocenti M, Matrisian LM, Tarkowski A. Metalloproteinase-7 contributes to joint destruction in Staphylococcus aureus induced arthritis. Microb Pathog. 2005;38(2-3):97-105. https://doi.org/10.1016/j.micpath.2 004.12.005.

176. Schönbeck U, Mach F, Libby P. Generation of biologically active IL-1 $\beta$ by matrix metalloproteinases: a novel caspase-1-independent pathway of IL-1 $\beta$ processing. J Immunol. 1998;161:3340.

177. Staurengo-Ferrari L, Trevelin SC, Fattori V, et al. Interleukin-33 Receptor (ST2) Deficiency Improves the Outcome of Staphylococcus aureus-Induced Septic Arthritis. Front Immunol. 2018;9:962. https://doi.org/10.3389/fimmu.2018. 00962.

178. Henningsson L, Jirholt P, Bogestål YR, Eneljung T, Adiels M, Lindholm C, et al. Interleukin 15 mediates joint destruction in Staphylococcus aureus arthritis. J Infect Dis. 2012;206(5):687-96. https://doi.org/10.1093/infdis/jis295.

179. Gjertsson I, Hultgren OH, Tarkowski A. Interleukin-10 ameliorates the outcome of Staphylococcus aureus arthritis by promoting bacterial clearance. Clin Exp Immunol. 2002;130(3):409-14.

180. Puliti M, von Hunolstein C, Bistoni F, et al. The beneficial effect of interleukin-12 on arthritis induced by group B streptococci is mediated by interferon- $\gamma$ and interleukin-10 production. Arthritis Rheum. 2002;46(3):80617.

181. Hultgren O, Kopf M, Tarkowski A. Staphylococcus aureus-induced septic arthritis and septic death is decreased in IL-4-deficient mice: role of IL-4 as promoter for bacterial growth. J Immunol. 1998;160(10):5082-7. 9590259.

182. Gilbertie JM, Schaer TP, Schubert AG, Jacob ME, Menegatti S, Ashton Lavoie $R$, et al. Platelet-rich plasma lysate displays anti-biofilm properties and restores antimicrobial activity against synovial fluid biofilms in vitro. J Orthop Res. 2020;38(6):1365-74. https://doi.org/10.1002/jor.24584.

183. Cho YJ, Patel D, Chun YS, Shin WJ, Rhyu KH. Novel Antibiotic-Loaded Cement Femoral Head Spacer for the Treatment of Advanced Pyogenic Arthritis in Adult Hip. J Arthroplasty. 2018;33(6):1899-903. https://doi.org/1 0.1016/j.arth.2017.12.028

184. Hsu YH, Chen DW, Li MJ, Yu YH, Chou YC, Liu SJ. Sustained Delivery of Analgesic and Antimicrobial Agents to Knee Joint by Direct Injections of Electrosprayed Multipharmaceutical-Loaded Nano/Microparticles. Polymers (Basel). 2018;10(8):890. https://doi.org/10.3390/polym10080890.

185. Schultz BJ, Sweeney T, DeBaun MR, Remmel M, Midic U, Khatri P, et al. Pilot study of a novel serum mRNA gene panel for diagnosis of acute septic arthritis. World J Orthop. 2019;10(12):424-33. https://doi.org/10.5312/wjo.v1 0.112 .424 . 
186. Zhao J, Zhang S, Zhang L, Dong X, Li J, Wang Y, et al. Serum procalcitonin levels as a diagnostic marker for septic arthritis: A meta-analysis. Am J Emerg Med. 2017;35(8):1166-71. https://doi.org/10.1016/j.ajem.2017.06.014.

187. Maharajan K, Patro DK, Menon J, Hariharan AP, Parija SC, Poduval M, et al. Serum Pro-calcitonin is a sensitive and specific marker in the diagnosis of septic arthritis and acute osteomyelitis. J Orthop Surg Res. 2013;8:19. https:// doi.org/10.1186/1749-799X-8-19.

188. Sultana S, Bishayi B. Etoposide-mediated depletion of peripheral blood monocytes post $S$. aureus infection attenuates septic arthritis by modulating macrophage-derived factors responsible for inflammatory destruction. Immunol Lett. 2020;220:51-62. https://doi.org/10.1016/j.imlet.2020.02.001.

\section{Publisher's Note}

Springer Nature remains neutral with regard to jurisdictional claims in published maps and institutional affiliations.

Ready to submit your research? Choose BMC and benefit from:

- fast, convenient online submission

- thorough peer review by experienced researchers in your field

- rapid publication on acceptance

- support for research data, including large and complex data types

- gold Open Access which fosters wider collaboration and increased citations

- maximum visibility for your research: over $100 \mathrm{M}$ website views per year

At BMC, research is always in progress.

Learn more biomedcentral.com/submissions 